\title{
EU CRISES AS 'CATALYSTS OF EUROPEANIZATION’? INSIGHTS FROM EUROBAROMETER DATA IN ROMANIA ON THE IMPACT OF THE REFUGEE CRISIS AND BREXIT
}

\author{
Miruna Troncotă, PhD \\ Alexandra Loy, PhD candidate \\ Department of International Relations and European Integration \\ National University of Political Studies and Public Administration (SNSPA) \\ Bucharest, Romania \\ miruna.troncota@dri.snspa.ro \\ alexandra.loy@student.dri.snspa.ro
}

\begin{abstract}
For the last decade, the EU was confronted with an unprecedented series of subsequent and often overlapping crises - the constitutional crisis, the Euro crisis, the massive influx of migrants and refugees and last but not least, the Brexit referendum. They were all very different in structure, but they had a common element - they put to test the European Union's (EU) legitimacy. The main assumption of the study is that these recent crises in the EU directly influence the debates in the national public spheres, and affect the way in which solidarity among EU citizens and EU states is imagined and enacted in media. Thus, the study aims to explain variation in the Romanian public opinion for the period 2014 to 2017. It identifies exogenous factors that relate to the EU polity, its policies and national politics and how they shaped public debate in Romania around two main Pan-European crises - the refugee crisis and Brexit. The paper discusses the impact of the two crises on the Romanians' level of trust in EU institutions and assesses possible causes of this 'superficial Euro-enthusiasm' on the overall context of the Europeanization of public sphere in Romania. The findings are discussed in light of three main conditions of a Europeanized
\end{abstract}


national public sphere: the role of Romanian media in building EU legitimacy; very high levels of polarization and contestation around the 2 topics of common concern; and a clear 'European dimension' that transcends national topics.

\section{Keywords}

Brexit, European Union; European public sphere, Europeanization, refugee crisis, Romania.

\section{INTRODUCTION}

For the last decade, the EU was confronted with an unprecedented series of subsequent and often overlapping crises - the constitutional crisis, the Euro crisis, the massive influx of migrants and refugees and the Brexit referendum. They were all very different in structure, but they had a common element - they put to test the European Union's (EU) legitimacy and pointed towards its much discussed 'democratic deficit'. In almost all of those crises, public discourses highlighted that that EU's existence is put under question. There is a need to analyse the ways in which these 'narratives of crises' inside the EU influenced the public opinion in member states. In this context, we believe that a relevant timeframe to test this assumption should comprise the multiple crises that hit the EU in the last four years, while assessing their impact on the citizens' public opinion at the level of a new member state- Romania.

In the literature, it is assumed that heated debates over controversial political issues that split the EU are a way to raise the level of interest in European issues which was considered as an indicator of Europeanization and a condition for the creation of a European Public Sphere (EPS). The habermasian notion of public sphere is most commonly referred to as a space or arena for public deliberation, discussion and engagement in societal issues. Regarding the emergence of EPS, a vast majority of researchers have adopted a media-related approach, with a rather quantttiative focus, through which the number of media outlets' references to EU actors, policies, and politics is examined, while at the same time the content of the relevant information is analysed with discourse analytical 
tools. The dominant assumption of this strand of research is that the increase of the EU's visibility within media outlets will render the emergence of an EPS plausible. The EPS was discussed in particular in the light of European integration and a European polity and it was further connected with the debate on Europeanization, at the intersection of different fields of social sciences. The current study opts for an interdisciplinary aapproach building between conceptualizations in media and communication studies and European studies. Thus, this interdisciplary views argues that news coverage about the EU has the potential to inform citizens about matters of European integration but also to engage them in debates about EU's legitimacy that reduce EU's democratic deficit and increase Europeanization in national public spheres.

It was extensively discussed in the literature that in the last decade, EU has passed through a series of difficult crises which have directly influenced how citizens perceive the EU. News coverage plays an important role in questioning or legitimising these social changes and continuities from the EU level to national and local level in each member state. Thus, the level of Europeanization of national public spheres became a concern for scholars and policy makers alike. Internal problems of the European Union have generated a constant decrease of trust and enthusiasm towards the European project, especially in the new member states. But Romania stands as an exception. Particularly for analysing European public sphere, the case of Romania is very intriguing. On one hand, Eurobarometer statistics showed for years that Romanians are Euro-enthusiasts, trusting more EU institutions than national institutions. On the other hand, research on the presence of EU-related topics in national media shows very little interest in what happens in Brussels, with the exception of particular events and crises (mostly with a negative connotation). The whole picture is puzzling Romanians hold a good image of the EU and they trust its institutions, but at the same time EU affairs are absent from prime time news and Romanian consider themselves as not being 'well informed about EU. We believe there is a need for more in-depth reflection of this particular example of Europeanization of national public sphere.

As such, we formulated the following research questions that guide the study: (1) What is the impact of these crises on the Romanians' level of trust in EU institutions and 
overall public opinion? (2) How can this impact be interpreted in the overall context of the Europeanization of public sphere in Romania? To answer these questions, an analysis of Eurobarometer data was conducted together with the study of explanations found in the literature regarding the type of Europeanization of the Romanian public sphere. For evidence of these processes we have compiled information from 8 Eurobarometers (from no. 81 in May 2014 to no. 88 in November 2017). We have chosen a very recent timeframe (2014-2017) in which EU was marked by multiple crises and a particular case study - a new member state - Romania, with one of the highest levels of Euro-enthusiasm in EU member-states. The paper analyses whether the two crises (the refugee crisis and Brexit) have induced a change in the degree of Europeanization of national public spheres in the case of Romania. Based on these elements, we hypothesize that the polarization of opinions about EU matters could be considered as an indicator of Europeanization of the national public sphere. We are thus interested to understand whether there is an explicable connection between the high level of polarization that affected the domestic debate in Romania and the level of Europeanization of public opinion as reflected in the evolution of the citizens' trust in the EU.

Based on Meijers' theoretization of EU crises as 'catalysts of Europeanization' (2013), we considered the two major events that marked the period between 2014 and 2017 as 'critical conjunctures' - moments of crises- atypical circumstance compared to the progression of European integration before. We wanted to see if those critical situations (refugee crisis and Brexit referendum inside EU) were likely to increase the degree of Europeanization of national public spheres in the case of Romania. In order to assess the extent and substance of the 'European dimension' in Romanian public sphere and how it has has changed during the periods of crisis, a cross-temporal element has been included. As such, we argue that there is the need to analyse the ways in which these 'narratives of crises' inside the EU influenced the public opinion about the EU in Romania.

The study was organized as follows: In the first section we tried to offer a synthesis of the most relevant recent theoretical debates on Europeanization and European Public Sphere within two fields of study - EU integration and communication/ media studies, highlighting also the challenges of this 
interdisciplinary perspective. We opted for a circular definition of Europeanization which analyses domestic change. This definition of EPS and Europeanization as a transnational space of communication that includes citizens and non-state actors is in direct connection with the multi-level governance approach in EU studies and will be used in this study. In the second section we discuss the main methodology and how data was interpreted based on a three factor analytic model. The three indicators of Europeanization/conditions for EPS were discussed in more detail, stressing their relevance for the current case study: (1) The role of national media in building EU legitimacy; (2) Polarization and contestation around a topic of common concern; (3). The European dimension that transcends national topics. The third section presents the main findings of the case study - we analysed Eurobarometer data, together with a series of national opinion polls about the two crises together with the study of explanations found in the literature regarding the type of Europeanization of the Romanian public sphere. Conclusions show that these moments of crisis are relevant for constructing an EPS (that manifests also at national levels) by creating a 'de facto' solidarity and a 'we'-feeling, despite the radically different opinions they generated.

\section{DEFINITIONS OF EUROPEANIZATION AND THE EUROPEAN PUBLIC SPHERE}

\subsection{The challenges of inter-disciplinarity}

In the last 20 years, Europeanization became one of the dominating research agendas in EU studies and it has penetrated many other subfields in social sciences. Looking at the evolution of the concept and the fierce debates it has triggered in the last two decades, Europeanization can be considered 'an unsettled research field' that remains to be explored, as many of its basic assumptions are still questioned. In the last decade in particular there was an exponential growth of literature that proposed complex analytic frameworks and various indicators on how to measure the level of Europeanization (see more in Ion 2016). 
There are many definitions of Europeanization, depending on the particular field in social sciences where the researchers originate. But there are some general features that almost all specialized scholars would agree upon, namely that Europeanization is a transformative process, taking place in a multi-layered space of deliberation and political negotiation and it becomes visible in different 'outcomes' or 'traces' that can be analysed (and sometimes even measured) through different theoretical and methodological lenses. We will not focus our efforts on proposing a new definition of Europeanization, but instead we will attempt to offer a synthesis of the most relevant elements in the recent theoretical debates on Europeanization within two fields of study - EU integration and communication/ media studies. Given the plurality of approaches to the empirical study on Europeanization in EU studies, one is confronted with an increasingly complex field of research which in the current paper will be approached in an inter-disciplinary manner. In order to do so, we will first sum up some important elements in the state of the art on the Europeanization research agenda.

The concept of Europeanization is understood as a transformation of various social and political factors in the framework of the EU, under the so-called 'transformative power of Europe' (Borzel and Risse 2000). The basic meaning of Europeanization refers, therefore, to any process that is, at least in a certain perspective, EU-driven or under the influence of the EU and that implies a change of the status quo. Based on this argument, some authors prefer the term 'EU-ization' as more appropriate (see more in Flockhart 2010). Broadly speaking, change occurs when political behaviour at the EU level has a transformative effect on domestic political behaviour, (in terms of what was called top-down approach) as well as influence on public opinion. The increasing Europeanization of governance structures on one hand and the slow development of an active European form of citizenship on the other created the need for investigating how the EU shapes public opinion, in a subfield entitled the Europeanization of public spheres.

The term 'public sphere' is often related to the works of Jurgen Habermas and in particular to his book "The Structural Transformation of the Public Sphere" (Habermas 1962). He defines it as an arena for 'the perception, identification, and 
treatment of problems affecting the whole society' (Habermas 1962, 6). The concept assumes the fact that legitimacy requires citizens to hold beliefs about a political system. These beliefs should motivate them to support, accept obligations vis-'a-vis the system, and act according to its rules. Crucially, these beliefs and attitudes should be articulated in public discourse. It implies also that an inclusive and democratic public sphere depends on the active participation of speakers, the media and audience. And this showed the importance of the public sphere as a deliberative space where politicians and citizens meet, to the development of which the media can significantly contribute as a mediator. In more specific terms, scholars in the field of communication studies considered the formation of a European Public Sphere (EPS) a crucial factor for social and political integration in Europe and this is the main element of intersection with EU integration theory. The concept of EPS was initially developed in communication studies, based on the aforementioned Habermasian description of a space of communication between citizens and political actors for discussions on matters of common European interest. In the last two decades, this has already become an established field of study within the broader Europeanization research agenda. One of the first comprehensive definitions of the concept was introduced by Risse: "The European public sphere is a transnational community of communication which creates a collective European identity in the process of arguing and debating the common European Fate" (2003, 8). Ever since, extensive research has been conducted on the EU's visibility in the public space, as well as the ways in which the EU is framed and represented in news media in connection with the extensively discussed topic of EU 'democratic deficit' and its lack of popular legitimacy. The quest for the EPS has generated a number of fruitful studies that give insights into the status quo of this process of 'reorientation' of national forums of public communication on EU. The discussion on EPS has been subsumed to measuring the overall degree of Europeanization of public debate (see more in de Vreese 2007; Koopmans 2007; Lauristin 2007; Brüggemann, M. and H. Schulz-Forberg 2009; Koopmans and Statham 2010; Offerhaus, Mollen, Hepp 2014; de la Porte and van Dalen 2016). We need to highlight the fact that in media studies Europeanization is connected, among others, with the way national media presents/covers EU related news 
stories, together with the ways (and the frequency) in which national elites talk about the EU publicly. As such, a more specific concept appeared - the Europeanization of national public sphere, which has developed at the intersection of political theory, EU integration studies and communication and media studies. The ideal type description of the concept would imply that the relation between the European institutions and its citizens, moderated by the public opinion through mass-media, is the core of a functional EPS. But this kind of relation is also vital for the functioning of the EU as a whole while being the main connection point with EU studies. In the literature it was argued that this process of Europeanization of national public spheres has a vertical and a horizontal dimension (a distinction widely used also in EU studies- see Borzel 2003 or Radaelli 2003) and it implies an increased focus on the EU, as well as more attention to other European countries.The core political role of this process was also underlined, based on the fact that "a European(ized) public sphere is therefore expected to not only inform about the EU, but also to contribute to the legitimacy of the polity and the understanding of EU politics" (de Vreese 2007, 6). De Vreese also showed that in the context of European integration the underlying assumption is that a shared European space, a EPS may contribute to the public legitimacy of the EU polity and its policies, in much the same ways as have been suggested for national public spheres. In other words, 'a Europeanized public sphere' is a precondition for democratic decision making in the EU and this is where the concept overlaps with a significant part of the recent literature in the field of European Integration theory (see more in Wiener \& Diez 2009).

In conclusion, the multiplication of empirical studies and theoretical assessments of the scope and parameters of a 'Europeanized' public space that connects citizens from different member states, with state institutions, EU institutions and non-state actors inside the EU created serious divides between various disciplines of study focused on the generic notion of the 'EU's transformative power'. Kokhanova (2012) showed that the various definitions of the EPS in media studies coincide with different perspectives of Europeanization in EU integration theory, and most often they are based on the different functions it should achieve, as well as the main actors in focus. Following Kokhanova's 
analytical distinctions (2012) three main models can be proposed (at the intersection of EPS theory with EU studies):

- EPS as a network of many public spheres confined to the nation states (the intergovernmental model based on the bottom up definition of Europeanization);

- EPS as a a Pan-European media system, where the same topics, are discussed at the same time and with the same meanings; (a supranational model based on a top down definition of Europeanization);

- EPS as a pluralist system of communication, with overlapping national public spheres, political discourses and public contestations where the member states, the EU itself and other non-state actors interact (the multi-level governance model based on an integrated definition of Europeanization as defined by Radaelli (2004) which includes both vertical and horizontal elements).

This last theoretical model assumes that national public spheres are neither isolated one from another, nor constitute a common subnational public sphere; instead they interact actively, between each other and with the EU level, respecting each other. This definition of EPS and Europeanization as a transnational space of communication that includes citizens and non-state actors is in direct connection with the multi-level governance approach in EU studies and will be used in this study. In short, we will opt for a circular definition of Europeanization which analyses domestic change.

\subsection{Indicators of Europeanization and Conditions for EPS}

As mentioned, the fields of EU integration and communication studies use different operationalizations of the indicators to measure Europeanization, even if some of them occasionally overlap. One of the biggest challenges of interdisciplinarity when discussing the concept of Europeanization is that different 
definitions point towards distinct indicators to be used empirically. This is applicable both in the debates in EU integration studies (which use the term 'indicators' with the aim to measure the level of Europeanization) and in EU communication studies (which use the concept 'conditions for the EPS' with the aim to identify a pattern of Europeanization). There are many indicators proposed in the scholarly literature for measuring the level of 'Europeanization of the public sphere' in various comparative frameworks, so we wanted to avoid this confusion by creating a common analytical model from both fields of study. The theory on the EPS focuses on different types of conditions: the level of integration between various national public spheres, public attitudes to European integration in member states, trust in EU (in Standard Eurobarometer) or the frequency and content of media reports on EU-issues. Following Kokhanova's analytical framework $(2012,13)$, combining the research of Eder, Kantner and Risse, the main conditions of formation of an EPS synthetized from the relevant literature are the following:

- Same issues discussed in the same time period;

- Similar criteria of reference;

- the European dimension / Europe as a common concern;

- Mutual recognition of participants.

Along with these four conditions for the EPS discussed in the literature, other dimensions of Europeanization of national public spheres were introduced. Liebert and Trenz $(2010,17)$ distinguish three of them, according to the actors who take part in the public sphere: There are politicians, who generate proposals, decisions; there are intermediaries, the media, which transmit this information to broad public; and finally, there is the public, which receives information. On the basis of this distinction, three dimensions of Europeanization arise:

a. Europeanization as public contestation, which can be represented by debates in parliament, protest movements, street demonstrations;

b. Europeanization as mass mediation, the media coverage; and

c. Europeanization as public opinion formation, represented by citizens' attitudes and opinions.

Out of fall those distinctions in the literature, we took an inter-disciplinary path 
and we have chosen three main elements as indicators/conditions of a Europeanized public sphere, which will form the main elements of the analytical model in the current study. These three indicators of Europeanization/conditions for EPS shall be discussed in more detail, stressing their relevance for the current case study - Europeanization in times of multiple crises and its effects in a new member state:

\section{European Public Sphere}

Politicians

Journalists as Intermidiaries

\section{Citizens}
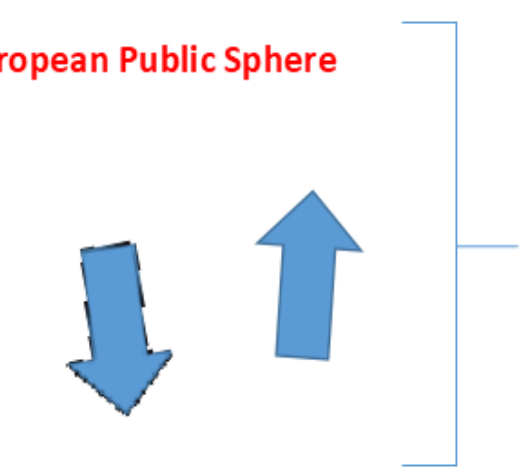

Europeanization

\section{National Public Sphere}

1. The role of national media in building EU legitimacy

2. Polarization and contestation around a topic of common concern;

3. A clear 'European dimension' that transcends national topics

Picture no. 1 The three main Indicators of Europeanization, edited by the author

a. The role of national media in building EU legitimacy

A lot of research has been dedicated to the visibility and prominence of European topics in the national media, their cognitive effects (framing) and impact on the citizens' agenda and citizens' trust in EU (de Vreese 2003; de Vreese, Banducci, Semetko and Boomgaarden 2006). As such, studies argued that the Europeanization of media coverage of the EU represents a crucial 
building block for developing a EPS. Moreover, they show that positive stories about the EU in media coverage increased trust in EU institutions. De Vreese and Boomgaarden (2006) found that when EU news coverage was frequent and positive in tone, the audience showed stronger support for the institution. Research shows that the positivity of stories regarding the EU in the press is in direct connection with the high level of trust in the EU as shown by the Eurobarometers (Brosius, de Vreese, van Elsas, Goldberg and Marquart (2017). During period of crises more negative news are expected, and so a decrease in the level of citizens' trust is also expected. Therefore, the scholarly literature concludes that media discourses about EU affairs play a key role in the Europeanization of the national public spheres. Research showed that a Europeanized national public sphere, taking, for example, Germany as a case study, is characterized by: salience of the discussion regarding European integration, European issues in media claim-making, positive evaluations of European issues and actors, which are less negative in comparison with those of national political actors (more in Pfetsch 2004). Previous research showed that trust in the EU depends on extrapolation from trust in national institutions, emotional attachment, and utilitarian consideration amongst other factors (Harteveld, Meer and Vries 2013). Brosius, de Vreese, van Elsas, Goldberg and Marquart (2017) showed that the media environment also contributes to shaping citizens' trust in the EU.

There were many critical voices who argued that the creation of a EPS is not feasible, thus it remains utopian in the absence of a pan-European media system, linguistic homogeneity and a unified European people. To what concerns the requirement of a common language, Koopmans (2004) argued that there is no need for a Europe-wide media based on a common language, as long as the media report about the same issues at the same time. He described this phenomenon as "parallelization of national public spheres" which he considers also a form of Europeanization of national public spheres (see also Eriksen 2005, Heikkilä \& Risto 2006, Kandyla and De Vreese 2011). Nonetheless, the lack of a EPS bears implications for the quest for legitimacy of the EU as it is most often associated with the democratic deficit and lack of accountability of officials before the electorate. In this case, scholars no longer search for a EU public 
sphere outside of or separated from national public spheres. The emphasis is rather on the degree to which the national public spheres are gradually Europeanized and European issues are regularly dealt with in the various national media (as underlined by van de Steeg and Risse 2010). De Vreese claims that "a well-functioning set of Europeanized public spheres may contribute to, facilitate, and mobilize both pro and anti-EU sentiments" $(2007,7)$.

Moreover, De Vreese (2007) argued that even if the EPS cannot be identified per se, it can still exist in the form of "Europeanized national public spheres". This phenomenon was called 'domestication of Europe', understood as the way in which "Europe" is communicated in national public spheres. The limits to the depth of Europeanization are generally explained through the lack of interest among ordinary people in EU information, and in the prevalence of nationalistic approaches to EU issues. Additionally, it was shown that "the general public usually become engaged in European issues only if they involve some national interest or are initiated by scandal or campaigns" (Eriksen 2005, 350). This coincides with Thomas Risse's definition of Europeanization as 'domestic adaptation of Europe' (2003). Baerthlein (2016) argued that transnational media (such as Euronews, EUObserver or Politico) is addressed only to a niche audience of Europe "insiders" and "influencers" rather than to the general public. In other words, the existence of the EPS is impossible in the absence of European media with a wide transnational audience. It is therefore natural that the perceptions of the same issue can be completely different across the $28 \mathrm{EU}$ member states and this phenomenon was called 'the segmented European public spheres'. These country-specific dimensions of 'framing Europe' are present not only in the media, but also among the discourses of elites and common people alike, and this applies to both Eastern and Western member states. Nevertheless, studies in the field have concentrated more on old member states and the way their national public spheres reflect EU topics, but the attention should turn to the new ones: on this subject, Lauristin argued (2007) that "the new members of the EU are even more interested in the development of the European public sphere than are many people in the West, because they see in this process their chance to be included in the European communication space as equal members. In order to reach this goal, the process of 'horizontal integration' between 
national public spheres and the development of the common social imaginary of the new Europe is considered to be very important" (Lauristin 2007, 1). Overall, the alternative proposed by authors is to focus on the national public sphere as a place where Europeanization takes place and where the EPS can be observed in a fragmented way. Back in 2007, Sifft et al argued that the EU remains largely dependent on domestic processes of legitimation and they suggested that what exists in reality (as shown by empirical studies) is a 'segmented Europeanization' of public spheres, which provides the EU only with limited legitimation resources; this implies that the EU still largely depends on domestic legitimation mechanisms, which have their limits when EU policies become contested among domestic actors and when domestic governments are not willing to act on behalf of the EU and legitimize such policies. The way EU is communicated at the national level is relevant for building legitimacy for the EU and for influencing public opinion. As such, the way EU is communicated impacts the trust of citizens in the EU. It is thus relevant to investigate the emergence of Europeanization in the context of national public spheres where these 'domestic processes of legitimation' take place focusing on the European dimension present in public debates and its impact on citizens trust in EU institutions.

\section{b. Polarization and contestation of EU around a topic of common concern}

Another important indicator/condition of the Europeanization of the public sphere, is that polarization and contestation (happening at national level), which were considered crucial 'for an emerging public sphere at the transnational level' (Risse 2010, 112). In previous studies, this idea was also stressed by De Vreese, who suggested that a 'conflict frame' in the media coverage on EU, with the potential to politicize more the EU in the eyes of citizens, contributes to the Europeanization of the national public sphere. De Vreese argued that "the conflict frame, a much applied journalistic news frame, can affect audiences so that additional thinking on EU politics is generated, while more positive and negative considerations might come to mind (De Vreese 2004). In times when decisions on both substantive and institutional issues are made an increase in contestation might be expected. Therefore, the Europeanization of national 
public spheres might become more visible when Europe's societies are confronted with a common crisis demanding contentious decisions) such as the refugee crisis or Brexit). It was shown that "the intensity of EU reporting always increases rapidly when a topic that is of EU-wide interest or at least popular in several EU member states is connected to a particular event" (Machill et al. 2006, 76). Those controversial issues manage to politicize EU by polarizing various actors in society and the topics that have this power are relevant for studying Europeanization of national public spheres.

\section{c. A visible 'European dimension' that transcends national topics}

Koopmans and Erbe (2004) proposed one more pre-condition, stemming also from the domestic level that should lay at the basis of the EPS: the European dimension of the issue/Europe as a common concern, which should be made visible to the public. They argued that if speakers discuss a European issue only from their national perspective, then it will not indicate Europeanization of the national public sphere. They have to realize that the question touches not only their country, but also other member-states. This particular 'European perspective' on national topics makes the debate 'Europeanized' as it manages to transcend national topics.

\section{THE EU'S CRISES AS 'CATALYSTS OF EUROPEANIZATION'? SOME METHODOLOGICAL CONSIDERATIONS}

For the last decade, the EU was confronted with an unprecedented series of subsequent and often overlapping crises - the constitutional crisis, the Euro crisis, the massive influx of migrants and refugees and last but not least, the Brexit referendum. They were all very different in structure, but they had a common element - they put to test the EU's legitimacy and pointed towards its much discussed 'democratic deficit'. In almost all of those crises, public 
discourses highlighted that that EU's existence is put under question. As we have seen in the literature, it is assumed that heated debates over controversial political issues that split the EU are a way to raise the level of interest in European issues. Could this mean that the EU's crises from recent years act as 'catalysts of Europeanization'? The following section explains the methodology and the analytical design of the study.

Particularly after the economic crisis, the EU was confronted with a renewed legitimacy crisis and needed a new story to tell to its citizens. This need has been addressed also at the official level, particularly by the European Union's project "A New Narrative for Europe" initiated by the European Parliament and implemented by the European Commission during 2013-14 at the end of Jose Manuel Barosso's mandate. But such initiatives did not have the power to provide a narrative that would also gain popular support. On the contrary, there are authors arguing that starting with 2014 new narratives started to promote a sort of transnational solidarity and elements of a European public sphere as an unexpected effect of various internal crises that the EU was confronted with such as the migration crisis, the Greek debt crisis or Brexit (Niznik 2017). There is the assumption that various "ad hoc transnational public spheres" were constituted by major crises in the EU in the last recent years. This is a challenging aspect that requires further research. Therefore, the need to analyse the ways in which these 'narratives of crises' inside the EU influenced the public opinion about the EU in Romania. In this context, we believe that a relevant timeframe to test this assumption should comprise the multiple crises that hit the EU in the last four years, while assessing their impact on both elites and the citizens' public opinion at the level of a new member state- Romania.

The main idea that we underline from Koopmans's work is that the EU's crises have the potential to increase actors' access to Europeanised policy debates. More precisely, "actors who have limited access to Europeanised public debates will also be critical of European integration and institutions, whereas the actors whose voices are most prominent in debates on European issues will be more favourably inclined towards European integration and institutions" (Koopmans 2007, 185). Meijers (2013) also addressed "the Euro-crisis as a catalyst of the Europeanization of public spheres", a metaphor that we also used for our 
analytical model. He focuses on changes in terms of visibility of European issues and in terms of salience of items on European issues during a major crisis. Niznik (2017) contributed to the debate by claiming that although the crisis had generated a radical split between the EU's societies, demonstrating sharp differences in attitude towards the fundamental European values, such as solidarity, at the same time it had triggered the emergence of a European public sphere, which until recently had been only theoretized. Hence, we forward the idea that sensational events, such as the crises affecting the EU, while triggering debates resulting in attitudes of polarization and contestation of the public sphere regarding European issues, are catalysts of Europeanization.

Saurugger (2014) also focused on how to study Europeanisation in times of crisis and she underlined three relevant factors to account for decision making and the impact these decisions then have at the domestic level during periods of high uncertainty: 'domestic' and 'European' timeframes; the salience of issues; and the politicization of citizens and actors. (Saurugger 2014, 181-186). The study shows that in general EU crises shorten the timeframe under which decision makers operate, they make problems more salient and lead to higher politicization in which routine decisions in specific sectors, or standard operating procedures, are very difficult to implement. Her work shows that time, salience and politicization play important roles in the acceptance or rejection of EU norms and lead to their renegotiation or adjustment at the EU level and we believe this becomes even more evident in the refugee crisis and after the Brexit vote. This entails a longitudinal analysis which will also be used in the current study. Given the magnitude of the polarized discourses they triggered, we believe that the period between 2014 and 2017 marked by multiple crises serves as a significant background against which the Europeanization of the member states' public spheres in a situation of uncertainty can be investigated.

We will conduct a case study analysis on Romania, a new EU member states which deserves a special attention from the perspective of Europeanization. On one hand, research based on Eurobarometer statistics showed for years that Romanians are Euro-enthusiasts, trusting more the EU's institutions than the national ones (Durach and Bârgăoanu 2014). On the other hand, research on the presence of EU-related topics in national media shows very little interest in what 
happens in Brussels, with the exception of particular events and crises (mostly with a negative connotation) (Radu 2013). The whole picture is puzzling Romanians hold a good image of the EU and they trust its institutions, but at the same time EU affairs are absent from prime time news and/or the print press. Therefore, we aim to answer the question "what are the main features of the European narrative in the case of Romania?"To answer this question, we have chosen a special period of time (2014-2017) in which the EU was marked by multiple crises, and thus its image in the media has been challenged. From this point of view, the case of Romania is very intriguing because it is a new member state that shares the same features of Europeanization as old member states such as Germany, while being very different from the Eurosceptic countries of the Visegrad group or other newer member states. Additionally, an important indicator of the Europeanization of the national public sphere can be identified in this time frame, namely the 'same criteria of relevance'. We built on the assumption that during a crisis the same issues are equally salient at transnational level. The crises which hit the EU in this interval of time - namely the migration and refugee crisis and Brexit - appeared to many Europeans as a serious threat to the unity of the European Union, which subsequently opened the space for a profound inquiry of both citizens and elites on the future of the EU (this became also the title of multiple consultations organized by EC President Jean Claude Juncker in March 2017). Based on these elements, we hypothesize that the polarization of opinions about EU matters could be considered as an indicator of Europeanization of the national public sphere. For the sake of our investigation, we also build on the idea of crisis as 'a catalyst of the Europeanization of public spheres' from Merijes (2013).

As explained in the previous section, the EPS is the space of contact between the EU and its citizens, but its impact is not uniform among EU member states because it is influenced by both internal and external factors, such as the type of media, the EU's institutional design and specific events. The EPS is not just an abstract notion or an ideal type, but it becomes visible especially during 'EU polity-related events' such as the European Parliament (EP) elections or European Council summits, but also by EP sessions when certain controversial matters that affect many people are debated publically. Thus, the space and time 
are two variables that need to be clearly determined in order to properly identify an instance of Europeanized public space. Most often than not this involves a member state as case study (or several in comparative methodology) and the selection of a specific time frame marked by relevant 'EU polity-related events' that could be associated with a visible impact on public opinion.

The main assumption that we want to empirically test with a focus on the evolution of Romanian citizens' trust in EU institutions is: In the selected period (2014-2017) EU crises had offered conditions for the Europeanization of Romania's public sphere, because through increased polarization they managed to bring 'more EU' in into public debates and thus, to make the "European dimension' more visible in the national public sphere. Moreover, the current study aims to focus on the specific dimension of Europeanization referring to 'Europeanization as public opinion formation' by studying comparatively evolutions in the Standard Eurobarometer's results from Romania and EU 28 in the period before and after the two major crises -that marked the EU in recent years - the refugee crisis and the Brexit referendum. Both events remain high on the EU's agenda and continue to stir discussions. Moreover, these are relevant moments because they have also triggered instititional changes and crucial decisions from the EU, each in different directions. The scope is to evaluate the effects of those subsequent crises on the overall trust in the EU of the Romanian citizens as an indicator of a Europeanized public sphere in Romania. For that purpose, we aim to present a chronology of key events in the period 2014-2017. More concretely we will focus more on the impact of those EU crises on national public opinion, namely how Romanian citizens perceived European issues and if their perceptions were affected by the two major crises - the migration crisis and Brexit. The media plays an important role in the process of opinion formation, so it is important to look at the types of opinions that citizens have (as reflected in Eurobarometers), in correlation with the types of messages that the media in Romania disseminates with regard to the EU. The media play the role of a filter; they select information in order to deliver it to readers; the emergence of social media also changed the situation. From this perspective, newspapers' articles are not very useful from our point of view to analyse the Europeanization of the public sphere because they are supposed to influence public opinion, rather than to build a dialogue 
and provide legitimacy to the EU. So where are the citizens in the EPS? To answer this question, as variants of framing the EU, neither newspaper nor online articles were used, but the Eurobarometer data about the meaning of the EU. The Eurobarometer is an indicator for how citizens made sense of different critical moments in the EU during the selected period. We wanted to see how two different types of crises, that marked the EU, have influenced what the citizens' perception about the EU in the case of a very Euro-enthusiast new member state like Romania. Following the tradition of European public opinion research on Eurobarometer data, we conceptualise the Europeanization of the Romanian public sphere as the degree of generalized long-term cognitions, orientations and attitudes toward the European Union and Europe as a political and social community. The empirical part of the analysis aims to analyse the variation in support at different periods of time up to the present, using data from the Standard Eurobarometer. The level of trust in the EU will be correlated with how various EU crises were reflected in the national media. Actually, previous research (de Vreese, 2003) points towards the fact that the 'key events` are essential in shaping public opinion about European affairs because they constitute the source of the (rather few) moments where the EU is visible in the mainstream news. These 'critical junctures' (as they are called in Historical institutionalism) are moments when important policy choices are required. In taking these decisions, the EU's representatives need to build popular legitimacy. Therefore, the analysis focuses on the selection of such key events in the EU in order to see their impact in the case of the Romanian public debate. Thus, the main research questions that guides the study are: (1) What is the impact of these events/crises on the Romanians' level of trust in EU institutions and overall public opinion? (2) How can this impact be interpreted in the overall context of the Europeanization of public sphere in Romania?

To answer these questions, an analysis of Eurobarometer data was conducted together with the study of explanations found in the literature regarding the type of Europeanization of the Romanian public sphere. For evidence of these processes we have compiled information from 8 Eurobarometers (from no. 81 in May 2014 to no. 88 in November 2017). Three main variables of the Standard Eurobarometer were selected as the main indicators measuring perceptions of 
the image of the European Union and its institutions and their respective trust ratings (see Annex 1):

-Trust in national governments and parliaments and in the European Union: trend

- Trust in the European Union: national results and evolutions

- The image of the European Union: national results and evolutions.

\section{EUROPEANIZATION OF NATIONAL PUBLIC SPHERE IN ROMANIA 2014-2017}

\subsection{The European Public Sphere in times of crisis. Overview and context}

Before analysing the impact of the two crises on the Europeanization of national public sphere, it is important to understand the overall period in which the events unfolded (with a short overview of relevant details about the periods before and after the crises reached their peaks). This first section aims to describe the overall European and national political context of the studied period and to reflect on the main features of the crises and their relevance for the polarization of opinions across the EU. This aspect is essential in order to connect it with domestic debates, positions and power games between actors involved in the Europeanization of the Romanian public sphere. Some trends in the EU and in Romania will be highlighted. De Vreese (2007) points to the fact that "the situation in which participation in EU politics was low, politicization absent, but public support high has changed so that EU politics can at times mobilize segments of the electorate (..) and under such circumstances questions about the public sphere become even more pertinent" (de Vreese 2007, 8). We believe this description fits the major events that marked both the EU and Romania politically in the period between 2014 and 2017 and we consider that in this context, questions about the Europeanization of the national public sphere in Romania becomes more pertinent than ever. 
The year 2014 represented a turning point for the EU for different reasons. First, there was the centenary of the beginning of the First World War after the assassination of Duke Franz Ferdinand in Sarajevo. Second, it brought a brand new institutional reshuffling in Brussels. Following the May parliamentary elections, the EU appointed its new leadership for the next 5 years. It was the first year with a European campaign for the European elections after the Treaty of Lisbon (Treaty on European Union - TEU) entered into force. The treaty brought significant institutional changes as an attempt to address concerns about democratic accountability and transparency in EU policy-making by granting a greater role to the directly elected European Parliament, national parliaments, and citizens' initiatives (more in Bărbulescu, 2015). Moreover, the TEU decisively strengthened the role of the European Parliament, empowering it to elect the candidate, rather than merely approving him or her. Specifically, Article 17 paragraph 7 of the Treaty on European Union states that a candidate for President of the European Commission is proposed by the European Council to the European Parliament, "taking into account the elections to the European Parliament and after having held the appropriate consultations" (www.lisbontreaty.org). The candidate is elected by the European Parliament by a majority of its component members under the Spitzenkandidaten system. As a result of the elections, Jean-Claude Juncker emerged as the lead candidate for the European People's Party and became the new President of the European Commission. And third, there was the spread of violence, insecurity and political turmoil in Ukraine (the annexation of Crimea by Russia and the violent conflict in Donbass, right at the EU's border), Gaza and Iraq/Syria. In this intricate context, all eyes were on the EU and its capacity to tackle these domestic and external challenges. (see more in Troncotă 2015).

Undoubtedly, the year 2014 had a special political significance for EU democracy and public discourse. But looking at it in terms of how citizens participated in these EU events, the perspective was rather gloomy, as the turnout in the 2014 European elections was the lowest in the history of the EU (See Table 1). An analysis of the figures for the 28 EU Member States shows that turnout was particularly low in countries of Central and Eastern Europe with Slovakia's EP election turnout set for the all-time low of 13\% (EU Observer 2014). It is 
important to add also that this was a rather medium term trend when the percentage of citizens with a positive view of the EU was on a downward slope, falling from 48\% in September 2006 to 35\% in September 2014 (European Commission, Eurobarometer data). Beyond the pessimistic media reports around the 2014 elections results pointing towards the fact that "never has the turnout at European elections been so low, and never the support for Eurosceptic parties so high as in 2014 elections" (Guardian 2014), it is important to note that low voter turnout does not necessarily mean dissatisfaction with the EU. But we need to underline the fact that voter turnout has been steadily declining since the first direct European election in 1979. It seemed as though the elections in 2014 would finally be the turning point of this phenomenon. The drop o however was not as drastic as in previous years. Several countries (especially countries in Central and Southeast Europe except Romania) noticed a significant drop in voter turnout, while others have noticed an increase (Romania). Part of the problem may be that Croatia did not vote in the 2009 elections, so their participation in the 2014 elections might have influenced the statistic a little bit. Voter turnout could be considered an indicator of how the Europeanization of the public sphere has evolved along the time, as well as an illustration of how citizens take part in European democracy (as the European Parliament is the only institution directly elected by the European citizens). Trenz (2014) explained that a 'post-heroic Europe' that emerged after the financial crisis "might also increase people's disengagement or dissatisfaction with politics" (Trenz 2014, 10) which was already confirmed by the low turnout in May 2014 European elections. 


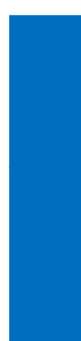

1979

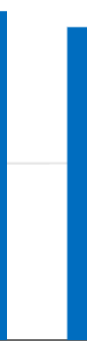

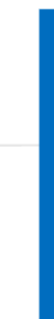
1984

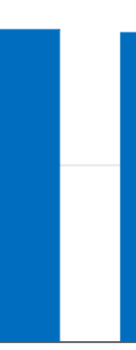

1989

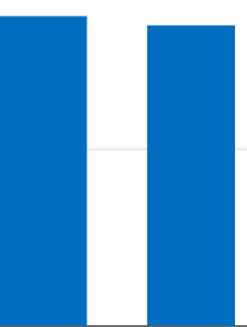

1994

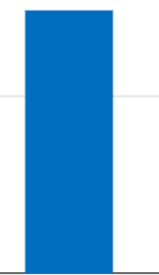

1999

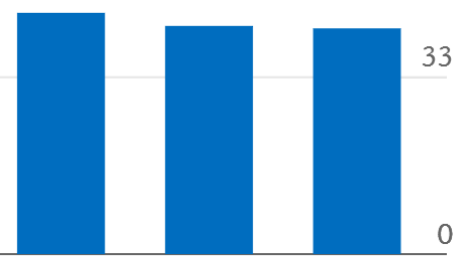

$20042009 \quad 2014$

Source: European Parliament

Table 1 source: http://www.europarl.europa.eu/elections2014-

\section{results/en/turnout.html}

Another aspect also needs to be underlined at this point - the fact that this round of elections has also noticed a mild increase in the amount of far right parties that strengthened their role in the EU Parliament (BBC 2014). This element would be critical during the two crises that we focus on - the refugee crisis and Brexit referendum - as this new Eurosceptic parties will play an important role in the 'negative' politicization of these European debates. The populist far right discourse has been a continuous trend over the last years, which has affected all of Europe. But the formation of Marine Le Pen's political group 'Europe of Nations and Freedom' (ENF) ${ }^{1}$ in the European Parliament in the summer of 2015 was the most visible result of this evolution and the results of the 2014 elections.

${ }^{1}$ ENF, presided by Marine Le Pen (Front National) and Marcel De Graaff (Partij voor de Vrijheid), comprises a total of 38 MEPs from eight Member States: France (Front National), Italy (Lega Nord), the Netherlands (Partij voor de Vrijheid), Austria (Freiheitliche Partei Österreichs), Poland (Kongres Nowej Prawicy), Belgium (Vlaams Belang), UK and Romania (both unaffiliated). 
Overall, the European Parliament elections in May 2014 demonstrated that Euroscepticism has grown, with right-wing, anti-EU parties gaining significant ground in France, Greece, the United Kingdom, Austria, and Denmark. More than a simple threat in internal political battles in Brussels, this phenomenon started to have a voice inside the EU's institutional system. The elected nationalist politicians advocate overt anti-EU policies such as less integration, more national control, anti-immigration policies, and stricter border security. This had an impact on both the refugee crisis and the Brexit referendum because a figure like Nigel Farage, a fierce Eurosceptic, also lead the 'Leave vote' campaign in Great Britain in 2016.

Romania also experienced a year with relevant political events in 2014. First, because Romania celebrated, along with the other Central and Eastern European states the 25 years anniversary since the fall of Communism. This occasion fostered many public debates, celebrations and remembrances of the Revolution in 1989, but also of the ups and downs of the prolonged transition period that lasted for a quarter of a century. Second, because Romania experienced a positive trend in European elections, reaching the highest turnout compared to Central and Eastern European states (Poland, Hungary, Czech Republic and Slovakia which had the lowest turnout of all EU28). It is interesting to note that the participation of Romanian citizens in EU elections grew visibly from 2009 $(27.67 \%)$ to $2014(32,44 \%)$ with almost $4 \%$. 


\section{European Elections - turnout in \\ Romania}

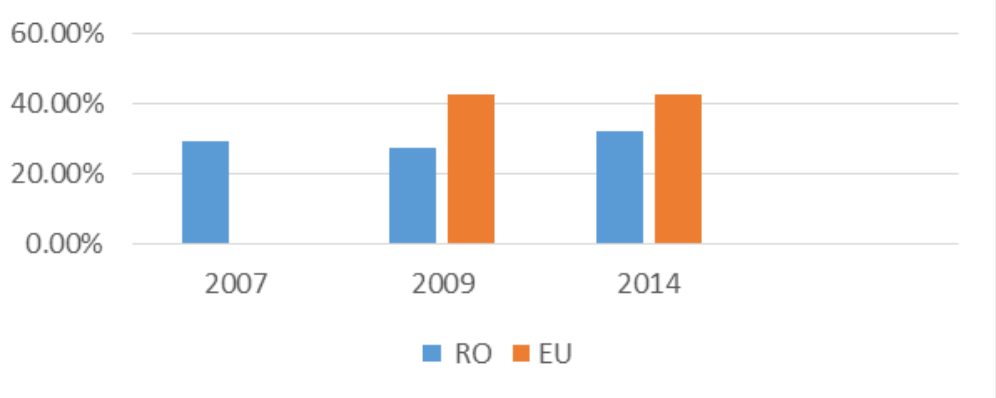

Table 2. edited by the authors based on European Parliament official data

These figures should also be compared to results from domestic elections, as 2014 was the year of new Presidential elections in Romania, just five months after the European elections. The overall turnout in these elections was high: about $64 \%$ of eligible Romanians voted in the second round on $16^{\text {th }}$ of November 2014, compared to $57 \%$ in the first round (2nd of Novemver) and an average of $53-57 \%$ in elections since 2000 (Brett and Knott 2014). It is also very relevant to underline that in 2014 there was also the highest participation in Romanian elections of the Romanian diaspora (see table 3).

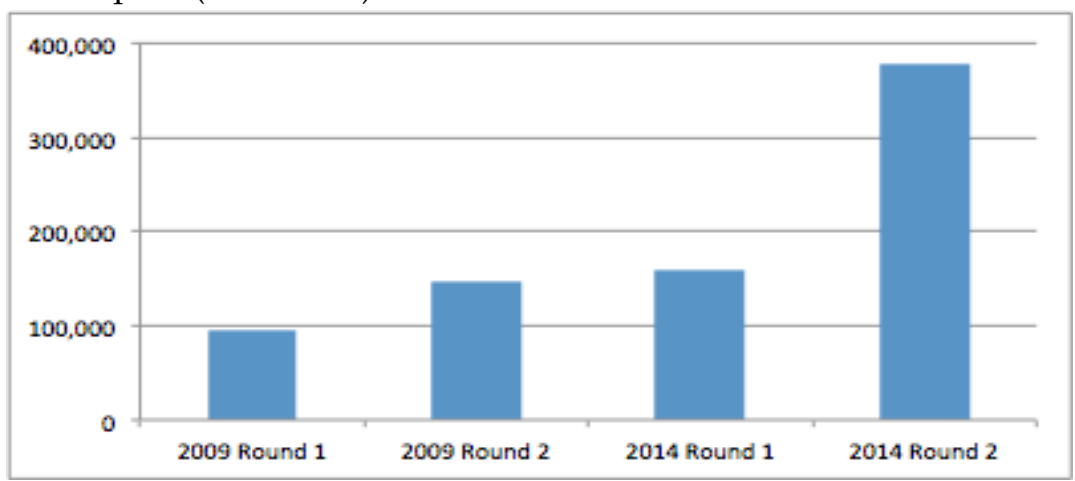

Table 3 source: http://blogs.lse.ac.uk/lsee/2014/11/19/2014-presidential-romanianelections-where-do-we-go-from-here/ 
The two main candidates were Victor Ponta, leader of the Social Democrat Party (PSD), the party occupied a strong position with a large, disciplined, welldeveloped and organised party infrastructure from a grassroots level across Romania, and Klaus Iohannis, Sibiu mayor (and ethnic Saxon), candidate of the Christian-Liberal Alliance (ACL). These elections had a huge political impact in Romania based on the polarized society and public debate at that time and this is how many explain the very high figures of turnout in the second round. Moreover, there was a huge scandal erupting during the first round, when "the large Romanian diaspora found itself unable to vote as huge queues appears outside embassies and official bureaucracy slowed the process to a crawl. After waiting for several hours to vote, thousands were turned away as the polling station doors were closed at 9pm sharp. Near riots followed and the police were called in London and Paris" (Brett and Knott 2014). Iohannis' victory was outright ( $\sim 55 \%$ by early polls) and shocking since many of those observers on the morning of the election were predicting an easy and decisive win for Ponta. In his analysis of the reasons for this result, Dâncu (2015) argues that "postmodern tribes' on Facebook were the ones that brought the huge score for President Iohannis building not only on a left-wing ideological divide, but also an offlineonline public communication divide and also on more nationalistic/ conservative messages (Ponta had a pro-Orthodox and nationalist electoral slogan) whereas Iohannis has a direct pro-European slogan. He also showed that "in the case of the presidential elections (in 2014), solidarity with the diaspora was spontaneously born, not only because nearly half of voters have relatives abroad, but also because many aspire to permanent immigration or simply to working abroad, while many others feel like strangers in their own country" (Dâncu 2015, 139). The 2014 Presidential elections also represented a turning point for the transformation of Romania's public space, because they brought the most relevant political debates in the virtual space and transformed the public space into an 'emotional space' a concept launched by Daniel Innerarity to define the climate in which new generations socialize and political decisions are taken (Innerarity 2006). The media reported that Ponta was defeated by the "Facebook party" or the so-called "Diaspora Party" which was a completely new 
actor in the Romanian political scene. Subsequent research by IRES (2014) has demonstrated that one quarter of voters decided between the ballots, and 32\% said they were influenced by the situation in the diaspora. Therefore, the internet became an important catalyst of protest and contagion, and it has mobilized significant sectors in the Romanian society, especially segments of the youth (which became more visible in the wide street protests for Colectiv from 2015 and in the 2017 anti-government manifestations).

Going further ahead in time, the period 2015-2016 was heavily marked by the socalled refugee crisis. In 2015, more than 1 million people (Reuters 2015), predominantly from Syria, Iraq and Afghanistan, tried to seek refuge in Southern Europe by crossing the Mediterranean on improvised boats. Most of them travelled onwards to Northern Europe, particularly to Germany and Sweden. These events have become known as the 'refugee crisis' and were highly politicized in most European countries, with the issue rising to the top of the public, political and media agenda at the EU and the national level during 2016. This crisis generated heated debates among elites at all levels of governance and citizens about the numbers of refugees that should be received and the conditions under which they should be given shelter in EU member states. The refugee crisis had a visible impact on domestic politics in member states, as the radical right rose in the polls even in countries which welcomed much lower numbers of refugees, such as the Netherlands and France, in comparison to Germany, the country which hosted the biggest number of refugees and where the radical right party Alternative fur Deutschland (AfD) rapidly picked up support since the summer of 2015. But above all, the refugee crisis impacted the EU itself, as its leadership was under difficult time constraints to make difficult decisions on how to deal with this massive influx of people. The High Representative of the European Union, Federica Mogherini, explained in the European Parliament in 2016 that the 'refugee crisis puts the European identity to the test' (EEAS 2016) showing the complex impact of this series of events on EU.

The main timespan of the refugee crisis that we took as reference point in the study is between September 2015 to April 2016. Wolf and Ossewaarde (2017) argue that September 2015 should be considered the beginning of the crisis in 
terms of public debates because this is the specific date of Aylan Kurdi's death (on the 2nd of September 2015) which led to a shift in public perception of the migrant influx in Europe (Wolf and Ossewaarde 2017, 5) The picture of the dead child on the Turkish shores became viral and stirred a global debate on the main responsibilities of the EU and member states to solve this problem. Wolf \& Ossewaarde (2017) also argue that since this date onwards public attention for the refugee influx increased substantially in Europe and the pressure for European decision makers to react likewise. Due to the EU-Turkey agreement in March 2016, the number of refugees crossing the sea from Turkey to Greece each day dropped from 853 per day in March 2016 to 137 in April 2016 (European Commission 2016). As such, the period from September 2015 to April 206 was considered the period with the highest public attention for the 'refugee crisis' and the greatest political pressure for European decision makers to react.

And finally, the year 2016 (with signs and debates even in 2015) was marked by the debates on the Brexit referendum, which is considered in the current study an EU crisis. In a speech given at Bloomberg on January 23rd, 2013 former Prime Minister David Cameron discussed the future of the European Union and declared he was in favour of an in-out referendum in the future on the basis of a new settlement for the UK in the EU (Gov.uk 2013). That was the moment that marked at the highest political level the acknowledgement on the part of the British decision-makers of the citizens' disapproval of the EU as well as the possibility that the United Kingdom would exit the Union. During his speech, David Cameron briefly stated the main reasons why the people's disillusionment with the EU was at an all times high at that point: the legal judgements, more precisely the European Court of Human Rights' rulings, made in Europe that impacted on life in Britain; the level of political integration that was far outside Britain's comfort zone, such as the changes in the Eurozone whose impact were unpredictable for a country that would have never joined it; the sharp decrease in the democratic consent of the citizen's for EU membership and last but not least, the failure of the people to accept a future European settlement over which they would have had little choice like the many treaty changes they had not been consulted for. Boris Johnson and Nigel Farage (leader of UKIP) were the lead figures of the Leave campaign, which fought under the banner of "Take back 
Control". Scholars underlined that this particular promise of "regained sovereignty', achieved by exiting the EU, played a significant factor in the British public debate (Wesselink 2017). With Brexit, the EU entered the year 2016 in a state of a 'deep existential crisis' as confirmed by Jean-Claude Juncker: "Never before have I seen so much fragmentation, and so little commonality in our Union" - declared the European Commission's President Jean-Claude Juncker in his "State of the Union" annual address to the European Parliament, on September 14th 2016 (State of the Union 2016, 6).

Despite the Government spreading a leaflet setting out the case for remaining in the EU to every household in the UK, the results of the in-out referendum scheduled on June 23rd 2016 were in favour of leaving the EU. Following this result, and as a staunch supporter of the in-camp, David Cameron resigned from office with Theresa May taking over as Prime-Minister. In respecting the result of the vote, May officially triggered - under Article 50 of the Treaty of the EU - the Brexit process on March 29th 2017 by notifying the President of the European Council, Donald Tusk, of the UK's intention to withdraw from the Union. All these events starting with 2016 and until spring 2017 will be referred in the article as the Brexit crisis. The confrontation between the Leave and Remain public Campaigns went far beyond the border of the UK, and involved wide audiences that took part in the transnational debate. As in the case of the refugee crisis, Brexit also touched the dimensions of European identity and challenged its status quo. This could be considered a proof for the existence of media effects on European democratic performance evaluations and it is worth examining its effects on the national public sphere.

In 2017, the EU celebrated a decade since it completed its Fifth or Eastern Enlargement with the accession of Romania and Bulgaria. This represented a particular moment for the re-evaluation of the impact of EU membership on each state in the last decade and a reflection on the main successes and drawbacks. At the same time, the year 2017 represented a huge milestone for EU integration, as the Union celebrated also 60 years since one of its main founding documents, the Treaty of Rome, was signed. This was considered by many as a proper time for re-evaluation of the European idea. On 1 March 2017, the European Commission presented a "White paper on the Future of Europe", setting out challenges and 
opportunities for Europe in the coming decade. Especially in the troubled context of the past few years which have been filled with challenges for the EU and its Member States: the Eurozone crisis, the immigration crisis, the rise of the farright and extremism and anti-EU sentiment, terrorism, and, perhaps the most challenging of all, Brexit. In Romania the year 2017 had a special political significance because it brought the biggest street protests since the Revolution in 1989. President Klaus Iohannis joined the protesters, sparking multiple critics for his position. The protests started at the beginning of February 2017 in the Victory Square in central Bucharest against the Grindeanu cabinet (PSD). The object of public anger was an emergency decree passed during the night that critics at home and abroad feared marked an alarming retreat in the battle against corruption. On February 26 $6^{\text {th }}, 2017$ an image unseen before becomes viral worldwide- in the central square in Bucharest thousands of Romanians create a EU human flag with their phones and blue and yellow papers - associating the fight against corruption with the EU, and corruption with the socialist government in power. These events also deepened the polarization between left wing and right wing discourses, in which the EU was taken as a reference point (the parties in the opposition and the protesters focusing on pro-European discourse, and the parties in Government (PSD-ALDE) with an ambivalent discourse, but a more accentuated anti-EU tone.

In other words, 2017 was a turning point for the re-evaluation of major EU narratives, which have shaped both discourses and political action within the EU. We consider this element a potential 'catalyst for Europeanization' and the creation of a more critical EPS which became visible also in Romania. In this context, more or less Europe seemed to be the main dilemma at the heart of debates around the future of the European project during the two crises, while the various crises of the EU influence the debates in the public sphere, and affect the way in which solidarity among EU citizens and EU states is imagined and enacted. 
4.2. The EU's image in the Romanian public discourse (2014-2017)

In order to better contextualize the impact on the levels of trust of Romanian citizens of the two crises that the EU was confronted with it is also important to shortly describe the media environment in Romania and its general characteristics. Public debate through Europeanized (mass) communication has increasingly been presented in the literature as one important way to solve the problems of the EU's democratic deficit and its low level of legitimacy in decision making (Slaata 2006, 11). It is important to note also at this point that the discussion about the manner the EU is present in media coverage is also a very political one, because the public opinion on EU affairs is connected with the legitimacy of its decisions through a 'national framing' of the EU issues. Media becomes more than a simple mediator of political messages, but an actor that can directly influence citizens, especially during elections. Most sociologists agree on the fact that a certain selection of information provided by the media can change citizens' opinions and policy preferences. The recent scandals of Cambridge Analytica are also a relevant topic of study from this point of view. New information, as provided by the media, can therefore contribute to public thinking about and support for or aversion against different aspects of European integration. The whole debate about 'fake news' is crucial also for the new patterns of Europeanization and their consequences on how public opinion was shaped in recent years. The media (owned by either public broadcasters or transnational private companies) plays an important role in affecting citizens as to which topics to consider and what to think about European integration. It was discussed that the two crises that we focus on - the refugee crisis and Brexit both involved the instrument of 'fake news' for inducing certain messages in order to influence public opinion (more visible in social media interactions). The scholarly literature indicates that one of the most prominent debates in connection to an EU topic in the Romanian media was the proposal made by the French and German Ministers of Internal Affairs on the 21 $1^{\text {st }}$ of December 2010 to postpone Romania's accession to the Schengen area of free movement (Dobrescu and Bârgăoanu 2012). This proposal sparked a lively debate in the Romanian media, becoming the main European topic covered by Romanian newslets in the 
first months of 2011. At the time, the authors underline that "compared to the years prior to the 2007 accession, when the level of Euro-enthusiasm in Romania was the highest among the member states, the level of trust has been in a constant decline" (Dobrescu and Bârgăoanu 2012, 34). Durach and Bârgăoanu (2013) studied 'Euroenthusiasm' in Romanian Youth, showing high level of trust in the EU even after the Eurozone crisis. Compiled data on media coverage (Milewski and Gusek 2013) showed that pieces of news about the EU were underrepresented in the Romanian public debate. Most often the debate was driven solely by the political elites during the economic crisis (so few years before the two EU crises erupted) and one of its main characteristics is that it was not genuinely European, but largely national. In their intention to map the EU representations currently in circulation within the European countries, they have pointed that Romanian prime time TV news programmes construct the social representation about the EU (Milewski and Gusek 2013). The authors showed that in Romania most pieces of news about the EU were placed at the end of the programme, at the international news category $(2013,7)$. This can be explained by the fact that the information was taken over from the international news agencies. "Most of the time, the format and content of such information were unchanged. The small number and the position of news on the programmes show that the EU was not a significant topic for Spanish and Romanian channels" (Milewski and Gusek 2013, 7). Moreover, they argue that in Romania very few key leading European figures, who directly or indirectly are in connection with the countries' problems, and as such they are presented in the national news. This means that the topics on the European political agenda do not make it on the national media agendas (Milewski and Gusek 2013, 8). This confirms the general disinterest of main TV programmes/broadcasters for European news, in both new and old member states (Romania included) together with a trivialization and negative description of all aspects happening in the EU. Most of the monitored news had more negative rather than positive content. "In the case of Romania, the news emphasized the European stereotype about the country's immigration and poverty problems. The negative image of Romania in Europe and the lack of interest of the EU in Romania was the most used approaches" (Milewski and Gusek 2013, 8). The Romanian media environment 
thus followed the trend of the EU negative news, but it is interesting to note that this is not reflected at all in the levels of trust in the EU of Romanian citizens, which are some of the highest from the newer member states.

Previous research also points to the fact that the media coverage of the EU's socio-economic strategy is Europeanized, but that it remains a debate by and for EU-interested actors (Bârgăoanu 2014). “European topics are less visible than expected during periods of important European events, and media practices are centred on conflict and powerlessness frames, which in fact translate a range of attitudes specific to emergent democracies in the EU" (Corbu et al. 2013). In terms of public communication, research shows that in the context of the $2014 \mathrm{EU}$ elections national elites partly orchestrated a sort of 'retreat' into the national public spheres: "Romanian elites chose to normalize Europe and to narrate EU in a banal way" (Radu and Bârgăoanu 2015, 174). Their study found that "EU policies are mostly referred to as intervening factors for domestic matters, or represented as just marginal topics rather than issues of EU politics and policymaking" (Radu and Bârgăoanu 2015, 173). Moreover, they argued that the national elites play a key role in the 'nationalization' of European topics in the media, "by engaging in a blame-avoidance game, by tacitly agreeing not to bring Europe forward on the public agenda" (Radu and Bârgăoanu 2015, 163). Goudenhooft (2015) and Pricopie (2014) also analysed the way the Romanian political discourse uses the previous metaphors on Europe, in order to place the European Union in the national political context. She shows that "Europe/European Union becomes an omnipresent discursive actor that marks all the parliamentary plenary debates and acquires various dimensions depending on the social, economic and political context and the type of the topic debated" (Goudenhooft 2015, 773). Just like in other member states, Euroenthusiasm has been constantly decreasing in Romania since 2007, but still it was more than $10-15 \%$ above the EU 28 average. Compared to the years prior to the 2007 accession, when the level of Euro-enthusiasm in Romania was the highest among the member states, the level of trust has been in a constant decline (see also Bârgãoanu 2010).

Previous studies of public opinion and elite analysis pointed towards Romania's inexplicable EU enthusiasm as reflected in the polls. But realities of the news 
coverage on EU issues, as well as levels of information on EU show a low interest in EU subjects. Radu (2016), based on the Standard Eurobarometers implemented between 2007 and 2015, underlined that the EU is perceived as a better potential alternative to the national system of governance. The explanation highlights the fact that "the source of the Romanians' Euro-enthusiasm has national, rather than European roots. This phenomenon - called 'rational extrapolation' is emblematic for the countries where citizens see the European Union as a panacea for domestic problems that cannot be effectively addressed within the nation state" (Radu 2016, 122). An important implication of this explanation is that the so-called 'national proxies' (in this case disappointment with domestic politics and distrust in local politicians) play a leading role in shaping EU-related opinions and attitudes, determining Romanian citizens to project an idealized image of the EU that they admire only when compared with local alternatives. This positive image is not correlated with specific arguments to underpin the way the EU is perceived.

Radu and Bârgâoanu (2015) tried to identify the key narratives of Europeanization in the elites' discourse on the 2014 European Elections. They showed that the "Romanian elites - be them political, administrative, or mediarelated - declare themselves as euro-enthusiasts or euro-realists; at the same time, through a diversity of blame-avoiding games, they use the EU as a means of diffusing (national) responsibility for crisis-related hot topics, such as the implementation of austerity measures". They explained also that national elites "use the EU as a means of diffusing (national) responsibility for crisis-related hot topics, such as the implementation of austerity measures" (Radu and Bârgăoanu 2015, 163). Radu and Bârgăoanu (2015) stress that Romania enjoyed periods of Euro-enthusiasm (dominated by the narrative of 'triumphant Europeanism' according to Trenz's analytic model (2014) even during the previous crises of EU. This idealized version of the EU can also be traced in the ways in which elites narrate about Europe, which induces the ordinary citizen the idea of a 'paradise lost', of a 'lost promise' (Radu and Bârgăoanu 2015,175). Durach (2016) pointed towards the fact that elite discourse in Romania between 2011 and 2015 passed through a gradual transition from 'triumphant' to 'banal Europeanization'. Those actions go against Europeanization, underlining that "the Romanian elites 
contribute to the so-called 'banalization of the EU'. This points towards a general trend of EU blame-shifting by national elites (that is recurrent most visible in times of crisis) that other scholars have found even in old member states (Haverland et al, 2018).

In order to conclude at this point - the EU's image in the Romanian media in the years prior to the analysed period 2014-2017 was marked by few EU related topics covered (all with negative connotations, portrayed as a 'threat' to Romania - such as the Schengen vote) and with national elites that act as rather 'challengers' than 'advocates' of Europeanization.

4.3.Empirical findings on the Europeanization of the national public sphere in Romania during the refugee crisis and Brexit

This section discusses the main empirical findings regarding the influence of the EU's crises on the Romanian citizens' levels of trust and public support for the European Union.

The basic assumption of our analysis is that national media reported with more frequency the news about the crises that affected Europe such as the refugee crisis and Brexit. Moreover, Harteveld et al. (2018) demonstrated that the general inflow of asylum seekers into the EU (and the media attention to the general inflow) has increased the Euroscepticism; as such, we wanted to see whether this was also the case of Romania. We tracked public opinion by combining data from 8 reports of the Eurobarometer with a series of national opinion polls on attitudes towards EU topics (with a focus on the refugee crisis and Brexit).

Based on this assumption, one can also expect that such crises create a feeling of 'common fate' and a shared European public space emerges - citizens in different MS comment on the same topics (where are the refugees coming from? What will be done to solve the situation? Should we be afraid of them? etc). The increased use of social media also contributed to this situation of common objects of focus that went viral on the internet, creating new public spaces of debate. Certain images became viral on the internet (such as the image with a child dead on the Turkish seashore in the case of the refugee crisis or videos with Nigel 
Farage's discourses against the EU during the Brexit debate). Those online viral materials had a strong emotional impact and mobilized citizens from many countries to get engaged in these EU issues. The condition for these online fora for discussions (reflected also in national media) to be considered signs of a Europeanized public sphere was to share the 'same criteria of relevance' as defined by Risse (2009). This means that the European topic approached needed to have similar meaning structures and patterns of interpretation. It does not mean that participants have to similarly evaluate issues (this would be almost impossible), but that they can agree or disagree, criticize or support, but still have a common understanding of the matter. Moreover, they can defend their national interest in order to find a better solution for their own citizens, but it is important that they acknowledge some basic principles of the European commonwealth, such as having EU institutions, the EU normative foundations, some collective identity and common good finality. From this perspective both migration crisis and Brexit are such subjects that created different opinions and were highly commented in the public media in all the EU's MS. The Brexit referendum in particular triggered debates about the EU's essence and questions regarding its 'common good finality'. We interpret this as a shared public sphere in Habermasian terms - in which different actors express different opinions and a common subject of interest using this "European dimension" as the same criteria of relevance that connects national public spheres all over the EU.

The general overview shows that in the Romanian public discourse, the EU was used as a source of division which increased polarization of public opinion, rather than as an element of shared beliefs. We analysed the Romanian citizens' evolution of trust in the EU in the selected timeframe (2014-2017). The results point towards the fact the Europe worked as a new conflict dimension in the public sphere, which added a new political cleavage between opposing political agendas (already heavily crystalized in the 2014 elections). European integration and thus Europeanization that comes with it is seen as dividing national audiences in 'winners' and 'losers' in relations with the EU, which created a more polarized public debate. Such conflicts of interest threaten to further develop into a new pro- and anti-integration cleavage in national public spheres; for example, there is already a rise of xenophobic and anti-European parties in 
many EU-countries as it was demonstrated by the 2014 European elections. Based on these general observations, we argue at this point that those two crises managed to 'bring the EU in the polity' - so citizens started to express more visible opinions about EU affairs - 'yes we welcome refugees, no we are against refugees or the leave and remain positions proposed by the Brexit referendum, which divided also countries in the EU in two opposite groups of supporters. This polarization was clearly visible in the Romanian public discourse particularly during the refugee crisis (Sebe, 2015/2016; Momoc, 2016).

Public opinion about European issues is in general very volatile. But there are two main general trends that we identified in the Eurobarometer data (and a set of national polls on the two crises) regarding the type of Europeanized national sphere in the view of Romanian citizens:

a. 'superficial Euro-enthusiasm', as a compensation for distrust in national institutions;

b. increased polarization in domestic politics which in turn influenced increased polarization on EU topics.

As seen in the surveys on public opinion (see tables 5, 6, 7 and 8), Romania is perceived as one of the most enthusiastic supporters of the European Union. The EU's internal problems have generated a constant decrease of trust and enthusiasm towards the European project, especially in the new member states, but Romania stands as an exception. The public opinion in Romania constantly remains less Euro-sceptic than the average. Romanian attitudes vis-àvis the EU are consistently favourable, but this is not sufficient evidence of an appreciation for the European Union as it reflects a distrust in national institutions. Sebe explains this uncertainty: "Romania has always been a Europhile country. Polls suggest a high rate of confidence in the European Union institutions, higher even than for national authorities. Yet, this may not be a clear sign regarding what the EU really means, but rather a sign of distrust in the national administrative system" (Sebe 2016, 2). Moreover, recent reports showed that "on a general basis, that between the 2007 accession and the current moment, few disturbing events have diminished Romanians' trust in the European Union, their enthusiasm to support an accelerated European integration having both a social-economic motivation and one based on the 
feeling of belonging to the European community of values. Ten years after accession, Romanians' trust in the European Union continues to be above the European average (52\% vs. 36\%)" (Mocanu, Mureșan, Vaș and Sebe 2017).

As the Eurobarometer data shows, EU actors are treated less critically than the national ones (with a huge difference $-20 \%$ more trust in EU institutions than trust in national institutions). But this is not automatically an indicator of a more Europeanized national public sphere in Romania. In the latest Eurobarometer survey that we included in the analysis (from November 2017) it turns out that $55 \%$ of EU citizens do not trust the EU, against the $33 \%$ that do. If we want to understand the situation in perspective, it is important to underline that the percentage of citizens who trusted EU underwent a substantial decrease since 2004 when the trust point was around $50 \%$. In addition, only $34 \%$ of EU citizens have an overall positive image of the EU, against $38 \%$ who are neutral and $27 \%$ with a negative view, i.e. a total of $65 \%$ of EU citizens have a non-favorable image of the EU. This is indicative of the increasing alienation that the EU citizens feel in relation to the EU decision-making process or, as it is termed in the relevant academic scholarship, the EU's 'Democratic Deficit'.

These findings need to be properly contextualized with the domestic political debate in Romania in the period between 2014-2017. The latest years have shown a drastic political polarization of the main TV channels in Romanian, especially based on the divide in domestic political life (left wing party PSD and the divided opposition PNL, USR). The Romanian citizens appear to vacillate between mild 'euro-enthusiasm' and downright 'euro-apathy'. In the spring of 2014 the majority of Romanians have a positive image of the EU (59), while the negative image of the EU is held only by $9 \%$, a score which is much lower than the average negative image on EU in the EU 28 countries (22\%). The public trust in the national institutions is lower than the trust in the European institutions by an average of 30\%, with the lowest record in May 2016. This indicates a big difference from other EU states that presented clear signs of Euroskepticism which are absent from the Romanian public sphere. This negative image was confirmed also in May 2014, when the lowest turnout in the history of EU elections was registered. The 2014 low turnout in the European Parliament elections is seen as a critical test for EU democracy, and a real legitimacy crisis in 
the EU.

The EU has a very visible positive image in the eyes of Romanians compared to the average of EU 28 countries. Every year there is a visible higher trust in the EU compared to the trust in national institutions. Trust in the EU in the view of Romanian citizens has a much higher score than in the other countries. The worst placed in the level of trust is the Parliament. The difference between the trust in the EU and national institutions is more than $10 \%$. This situation very much contrasts with other EU members, where EU citizens continue to experience a low level of trust in the EU; at the same time, they have grown more confident in their national parliaments and governments. Recent years witnessed a growing opposition to the EU that can be easily seen in the Eurobarometers (decreased trust in EU with few percentages every year). The trend is reversed in the case of Romania. The level of trust and the positive perception of the EU in the eyes of the Romanians has been following this trend too (it decreased every year since 2014) but there is still a visible and rather high difference compared to the EU28 average (see table 5). It is interesting to correlate this level of visible Euroenthusiasm of Romanian citizens with the levels of information on EU matters (as measured by the Eurobarometer (Media use in EU) (see Table 4). Romania follows the general EU 28 trends - $30 \%$ of the respondents declare that they consider themselves well informed about the EU (only $3 \%$ higher than the EU 28 average), and a more than double percentage, $67 \%$, consider themselves rather "not well informed" about the EU. The picture than we can draw from these data is rather paradoxical - Romanians have more trust in EU institutions than other European citizens (and the EU 28 average), but still a majority of them consider themselves as "rather not well informed about the EU". This points towards a sort of 'superficial trust' in the EU, not based on information and not emerging as a direct consequence of a Europeanized public sphere, but rather as a counterpart to the very low levels of trust in national institutions. In other words, Romanians tend to project certain hopes and positive projections on the EU (based on limited information on the EU), as a compensation for their distrust in the Romanian political class. 


\section{Level of information on EU matters among Romanian citizens}

\begin{tabular}{|c|c|c|c|c|c|c|c|c|c|c|c|c|}
\hline & \multicolumn{3}{|c|}{ Autumn 2014} & \multicolumn{3}{|c|}{ Autumn 2015} & \multicolumn{3}{|c|}{ Autumn 2016} & \multicolumn{3}{|c|}{ Autumn 2017} \\
\hline & $\begin{array}{l}\text { We } \\
\text { ll } \\
\text { inf } \\
\text { or } \\
\text { me } \\
\text { d } \\
\text { (tot } \\
\text { al) }\end{array}$ & $\begin{array}{l}\text { Not } \\
\text { well } \\
\text { infor } \\
\text { med } \\
\text { (tota } \\
\text { 1) }\end{array}$ & $\begin{array}{c}\text { Total } \\
\text { ly } \\
\text { unin } \\
\text { form } \\
\text { ed }\end{array}$ & $\begin{array}{c}\text { Wel } \\
1 \\
\text { info } \\
\text { rme } \\
\text { d } \\
\text { (tot } \\
\text { al) }\end{array}$ & $\begin{array}{c}\text { Not } \\
\text { well } \\
\text { info } \\
\text { rme } \\
\text { d } \\
\text { (tot } \\
\text { al) }\end{array}$ & $\begin{array}{c}\text { Total } \\
\text { ly } \\
\text { unin } \\
\text { form } \\
\text { ed }\end{array}$ & $\begin{array}{c}\text { Wel } \\
1 \\
\text { info } \\
\text { rme } \\
\mathrm{d} \\
\text { (tot } \\
\text { al) }\end{array}$ & $\begin{array}{l}\text { Not } \\
\text { well } \\
\text { infor } \\
\text { med } \\
\text { (tota } \\
\text { l) }\end{array}$ & $\begin{array}{c}\text { Tot } \\
\text { ally } \\
\text { uni } \\
\text { nfor } \\
\text { me } \\
\text { d }\end{array}$ & $\begin{array}{c}\text { Wel } \\
1 \\
\text { info } \\
\text { rme } \\
\mathrm{d} \\
\text { (tot } \\
\text { al) }\end{array}$ & $\begin{array}{c}\text { Not } \\
\text { well } \\
\text { info } \\
\text { rme } \\
\mathrm{d} \\
\text { (tot } \\
\text { al) }\end{array}$ & $\begin{array}{c}\text { Totall } \\
\mathrm{y} \\
\text { uninfo } \\
\text { rmed }\end{array}$ \\
\hline $\begin{array}{l}\text { EU } \\
28\end{array}$ & $\begin{array}{c}26 \\
\%\end{array}$ & $70 \%$ & $4 \%$ & $\begin{array}{c}31 \% \\
\uparrow\end{array}$ & $\begin{array}{c}65 \% \\
\downarrow\end{array}$ & $4 \%=$ & $\begin{array}{c}28 \% \\
\downarrow\end{array}$ & $\begin{array}{c}68 \% \\
\uparrow\end{array}$ & $\begin{array}{c}4 \% \\
=\end{array}$ & $\begin{array}{c}31 \% \\
\uparrow\end{array}$ & $\begin{array}{c}65 \% \\
\downarrow\end{array}$ & $4 \%=$ \\
\hline $\begin{array}{l}R \\
O\end{array}$ & $\begin{array}{c}30 \\
\%\end{array}$ & $67 \%$ & $3 \%$ & $\begin{array}{c}39 \% \\
\uparrow\end{array}$ & $\begin{array}{c}58 \% \\
\downarrow\end{array}$ & $3 \%=$ & $\begin{array}{c}35 \% \\
\downarrow\end{array}$ & $\begin{array}{c}62 \% \\
\uparrow\end{array}$ & $\begin{array}{c}3 \% \\
=\end{array}$ & $\begin{array}{c}31 \% \\
\downarrow\end{array}$ & $\begin{array}{c}66 \% \\
\uparrow\end{array}$ & $3 \%=$ \\
\hline
\end{tabular}

Table 4 Data compiled by the authors from the Standard Eurobarometers "Media use in European Union" 82, 84, 86, 88)

The other potential explanatory factor for these findings is Romania's discursive polarization in domestic politics (which was the main reason for the protests in February 20171 and which associated the anti-corruption policies with EU values and EU membership, whereas the PSD-ALDE coalition in Government is associated with a strong nationalist agenda and with corrupt practices, which was portrayed by the protesters as 'anti-EU'). These very recent events created a discursive polarization in the perception of the EU - oscillating between narratives of 'triumphant Europeanization' with narratives of 'failure of Europeanization' and distrust. This divide became visible during the 2014 Presidential elections (within the online Facebook campaign won by Klaus Iohannis against the Socialist leader Victor Ponta) (Dâncu 2015), but more

${ }^{1}$ In February 2017, the Romanian parliament considered passing a bill that would have pardoned many officials who had already been convicted of corruption. This measure sparked mass demonstrations called the '\#Rezist movement' that rolled across Romania the largest street manifestations since 1989 - drawing more than half a million people and lasting for more than two weeks. 
straightforward it was shown in the 2017 anti-government protests. Carp (2015) also argued that "Romanians have a higher degree of confidence in the EU institutions (the European Commission, the Council and the Parliament of the European Union) than in the national ones, a fact that may be largely due to the local debate on corruption, in which corruption is almost entirely associated to the national institutions, not to the European ones" (Carp 2015, 4).

\section{Romanian perceptions of the Refugee crisis and Brexit}

The refugee crisis revealed growing xenophobia and hostility towards the 'others' - both in old and new member states (the Visegrad groups was one of the biggest opponents of the refugee quota system). In the autumn of 2015 (when the refugee crisis started to be the main topic in the European media) one can notice a visible decrease of Euro-enthusiasm in Romania (most visible in May 2016, at the end of the crisis - marked by the EU-Turkey accords). These results should be also correlated with other opinion polls focused on attitudes towards EU. For example, in 2015, the Konrad Adenauer Foundation conducted the survey "European Perceptions in Romania - 2015" (Carp 2015). It was focused on the general perceptions of Romanians concerning the position of Romania in the European context and it focused on what was called the well-tempered optimism'. The study showed that there is shift in the sources of information with $60 \%$ of Romanians get their information on the European Union from the Internet and only $40 \%$ from TV programs (Carp 2015, 2). This complemented another public survey called "European Union in Romanian's Perception", conducted by INSCOP Opinion poll (2015). The study underlines that as a result of a positive perception and of the benefits of EU membership, three out of four Romanians consider that the accession was a step in the right direction. Momoc (2016) explains that social media have been changing the Romanian perception related to refugees, asylum seekers and migrants focusing on the case of the former Romanian President, Traian Băsescu, who had an active role in the online hate speech against refugees. He shows that since the EU public debates on whether the refugee quotas should be mandatory or volunteer have intensified, the people's perception of refugees and the rejection became viral in the online 
environment. This is illustrated by the fact that in August 2015 the polls indicated that Romanians were in favour of accepting the immigrants, while in September 2015 more than half of the respondents declared they were against receiving refugees (Momoc 2016, 71).

This new cleavage brought by the debates around the migration policy is very significant for our assessment of the Europeanized public sphere in Romania. As resulted from the debates around the refugee crisis (2015-2016), there was a clear East-West divide on the refugee crisis. Countries in Central Eastern Europe lack the Western EU states' positive experiences with migration and multiculturalism, and have not received large influxes of people from outside Europe. Janning (2018) argues that "there appears to be a clear relationship between the crisis and the surge in support for populist parties across Europe, which have all picked up the issue of immigration and its impact on linguistic, cultural, and religious diversity" (Janning 2018).

Although it was not effectively targeted by the refugees among the main routes to the West (who chose neighbouring countries, such as Serbia or Hungary), Romania took part in the decision of the JHA Council (September 22, 2015) that established that refugees will be distributed to each country. According to the provisional quota system approved by the JAI Council, 2.475 refugees were allocated to Romania. The total number of immigrants so far allocated to Bucharest being 4,837. Romania has another 2,362 refugees under the JHA Council decision of 14 September on the distribution of 40,000 refugees (Mediafax 2016).

The Report issued by the Romanian NGO Pro Democracy Association (APD 2016) regarding Romanian citizens' perception of the refugee crisis shows that that the Romanian media was mainly limited to illustrating the statements of the main political decision-makers in Romania, without issuing separate opinions of those mentioned or without carrying out analyses of the deployment and the possible effects of the crisis of the refugees at European level or in Romania. In other words, the national media just reported these events, but did not take part actively in the pan-European debate. Journalistic accounts were thus rather passively identified in the EPS. The report shows that $48 \%$ of respondents perceive this crisis as a threat that contributes to political, social, territorial and 
economic instability, which has adverse effects on state security, many assimilating the crisis of refugees with terrorist threats (APD 2016, 18). Regarding the source of information of the Romanians about the current crisis, the report shows that the Internet and social networks are the first options for $55 \%$ of the respondents, $29 \%$ are informed by television and radio, and $14 \%$ get the information also from the written press.

Regarding the information on the refugee crisis, the report underlines that $99 \%$ of respondents said they had heard about this European problem and 1\% had not. Regarding the source of information of the Romanians about the current crisis, the Internet and social networks are the first options for $55 \%$ of the respondents, $29 \%$ are informed by television and radio, $14 \%$ get the information also from the written press, and the difference up to $100 \%$ is represented by other responses, such as friends, family and non-responses.

A similar result is offered by another national public opinion poll on the topic IRES Study on the Perception of Romanians on the Refugee Crisis (2015) - which was conducted in September, right at the beginning of the refugee crisis assessed Romania's perception of this phenomenon. It showed that $83 \%$ of people participating in the IRES study said they had heard about the immigration crisis at the borders of the European Union. According to the data, more than half of the Romanians - 57\% - consider the risk of Romania being exposed to an invasion of immigrants from the Middle East and Africa as low and very low, while $41 \%$ consider that this risk is high and very high . More than a third of the study participants - 35\% - assess Romania as "very poorly prepared" to cope with an immigration crisis in the Middle East and Africa, a similar percentage - $38 \%$ - assesses it as weak ready, while only a fifth of Romanians - $21 \%$ - believe that our country is prepared to cope with such a crisis. The study concludes that Romanians are undecided when they have to express their opinion on the reception of refugees in Romania with $65 \%$ of respondents agreeing totally or partially that Romania will receive a certain number of immigrants as part of its obligations as an EU member. But when asked about the possibility of refugees moving to their own place of living, the percentage of those who agree to this drops to $46 \%$, and $42 \%$ are totally rejecting this hypothesis. 
The influence of the Brexit debate and the referendum (that took place in June 2016) can be seen results in December 2016 - when trust in the EU registered a visible decrease at both EU level and in Romania.

According to the IRES Study on the Romanian perceptions on Brexit (July 2016) in the context of the UK referendum results, IRES investigated the perceptions of Romanian citizens about the British decision, but also their attitudes towards the European Union and the status of Romania in the Union. According to the findings of the study, the perceptions of the Romanians related to Brexit do not change the perception of the EU in the sense of trust in the European project and the desire to belong to the Union, although it shows that there is a crisis requiring a European reconstitution. 9 out of 10 participants in the study agree that Romania should play an active role in re-launching the European project, a slightly higher proportion (93\%) considering that Romania should show that it is still attached to the values and principles fundamental rights of the European Union. $69 \%$ of the study participants believe that Romania has more to gain by integrating into the European Union. $62 \%$ of the study participants who have heard of events in the UK believe that a European Union crisis can be solved.

Additionally, the Mercury research study (2017) public opinion poll showed that after 10 years of EU membership, the overall attitude of the respondents is $46 \%$ positive towards Romania's EU membership, compared to $14 \%$ that considered the contrary. Trust in the EU is rather high - $57 \%$ compared to lack of trust - $33 \%$, even if it has decreased compared to previous years. In this context, the narratives about EU present in the media and public space shape perceptions as well as determine politic action. The main characteristics of these narratives are an important indicator of on how the divisive and cohesive forces in the EU worked during the Brexit debate far beyond Great Britain society and media debates.

\section{CONCLUSIONS}

EU connects with its citizens through mediated communication. This proved to be both a limitation and huge opportunity for the authorities in Brussels. EU 
media coverage is thus a very political issue, which needs to be seriously taken into consideration when Europeanization is discussed, because as it is directly connected to EU's democratic deficit and it influences variations in public opinion and trust in EU institutions. The relation between the European institutions and its citizens, moderated by the public opinion through massmedia was defined in the literature as the core of a functional EPS (in Habermasian terms). Media content analysis and analyses on news coverage on EU point towards nationally segmented public spheres rather than an idealized EPS that transcends borders, and domestic issues and unite all citizens in the EU. But such a relation is also vital for the functioning of the EU as a whole during times of 'existential crises' as leaders in the EU called them. We are thus dealing with a EPS that is a result of the Europeanization of the national public spheres. We wanted to see how two different types of crises that marked the EU, have influenced what the citizens' perception about the EU in the case of a very Euroenthusiast new member state like Romania. Even if Romanians highly trust the EU more than national institutions, still, in media coverage the national dimension of public debate prevails. But literature on the topic showed that "domestication" of EU topics increases coverage and viewpoints.

In the end, the paper shows that the impact of the refugee crisis and Brexit on public opinion is relevant for discussing the Europeanization of national public sphere because they both received great coverage across media outlets in Europe and they manage to increase polarization between various segments of societies (at different degrees) in all member states. Both the refugee crisis and Brexit marked a turning point in EU affairs, triggering various levels of contestation and putting the whole EU rationale at stake. They could be considered even a sort of 'existential crises' for the Union because they required immediate reactions both at supranational level and in each member states, which involved repositioning of countries and EU institutions on the matter, together with taking difficult decisions and fining common solution which ended also with both calls for solidarity or polarization/ disintegration. As a response to the large refugee influx to Europe in 2015 and 2016, the so-called 'refugee crisis', and the Brexit referendum in June 2016 political decision makers have extensively discussed their perspectives and opinions on the European Union (EU) in the media. These 
debates have also impacted national public spheres in different member states. The current research focused on the impact of these events on Romanian national public sphere.

It is known that crises bring people together, even though they also polarize societies. In the case of EU, one can easily argue that the two major crises of the last years - the migration crisis and Brexit (very different from each other and with a strong impact on citizens' perceptions) - have polarized members states, EU institutions and citizens. Thus, a Europeanized public sphere is understood in the current study as a space of contestation and freedom of opinion about a 'common European fate'. The dilemmas brought by the crises proved relevant for constructing an EPS (that manifests at national levels) by creating a 'de facto' solidarity and a 'we'-feeling, despite the radically different opinions they generated.

Building on recent data from Romanian media and public opinion trends in Romania during the crises, the paper shows that historical moments when the EU is confronted with legitimacy crises and contestation offer important opportunities for research focused on the fragmented EPS. The recent 4 years were characterized by several such events, namely the refugee crisis and Brexit, that required national (and fragmented) efforts of legitimization from various political actors inside the EU. The findings showed that there is an explicable connection between the high level of polarization that affected the domestic debate in Romania and the level of Europeanization of public opinion as reflected in the evolution of the citizens' trust in the EU which reached its lowest point in the last decade at the end of 2017.

The Eurobarometer survey results from Romania and EU 28 average show that, despite the crises, the level of trust has only very little decreased compared to other countries. Based on these elements, the assumption that the polarization of opinions about EU matters could be considered as an indicator of Europeanization of the national public sphere was confirmed. All three main conditions were met in the case of Romania: (1) EU to be perceived as a legitimate political entity 9 the level of trust decreased - with its lowest point in 2017, but the scores are still visible much higher than EU 28 average; (2) High level of polarized opinion about the crises (refugees and Brexit sparked intense 
debates in Romanian media); (3) A European dimension of the debates was present, but still the overall trend of EU 'domestication' characterizes Romanian public sphere.

EU crises proved not be the only 'catalysts of Europeanization' in the case of Romania, where domestic issues remain prominent in structuring public debates. European issues were indeed more present in national public sphere, but there were no visible fluctuations of public opinion in the case of citizens trust in EU's institutions during the refugee crisis and Brexit debates. The assumption was not validated by the data, as we showed that the case of Romania has a series of paradoxical features: a form of 'superficial Euro-enthusiasm' (little information about EU but high level of trust in EU institutions, combines with very low trust in national institutions and $b$. increased polarization in domestic politics which in turn influenced increased polarization on EU topics.

In the studied period, in many member states nationalist and populist parties became more visible in public debates during the two crises. Even if this was not the case of Romania, several political elites adopted also this approach and have partially radicalized their views. These more visible political actors (such as former President Traian Băsescu during the debates on the refugee crisis) have strengthened the "us and them" narrative, which aimed to propagate anxiety in connection with the perceived 'others' - be it refugees, immigrants, foreign governments, unelected officials in transnational bureaucracies, or international courts that overrule national institutions. The research showed that polarization is the strongest predictor of a Europeanized national public sphere, but only if its in connection with a visible Euroean dimension of national topic. Despite the crises, the EU still has a very visible positive image in the eyes of Romanians compared to the average of EU 28 countries. Trust in the EU in the view of Romanian citizens has a much higher score than in the other countries.

All in all, the main assumption formulated in the beginning was confirmed - EU crises from the period 2014-2017 had only partially offered conditions for the Europeanization of Romanian public sphere, because through polarization they managed to bring 'more $\mathrm{EU}^{\prime}$ in into public debates and thus, to create a more Europeanized national public sphere. Further research needs to be conducted going beyond the Eurobarometer data, and correlating results with in-depth 
media coverage and qualitative content analysis of how Romanian media frames the 'European dimension" in the case of various other pan-European debates. 


\section{Annex 1 Eurobarometer surveys' results, compiled by the authors}

Table 5. Comparative trends in EU 28 and Romania - Trust in national governments, parliaments and the EU, edited by the author with data from Standard Eurobarometer 81-88

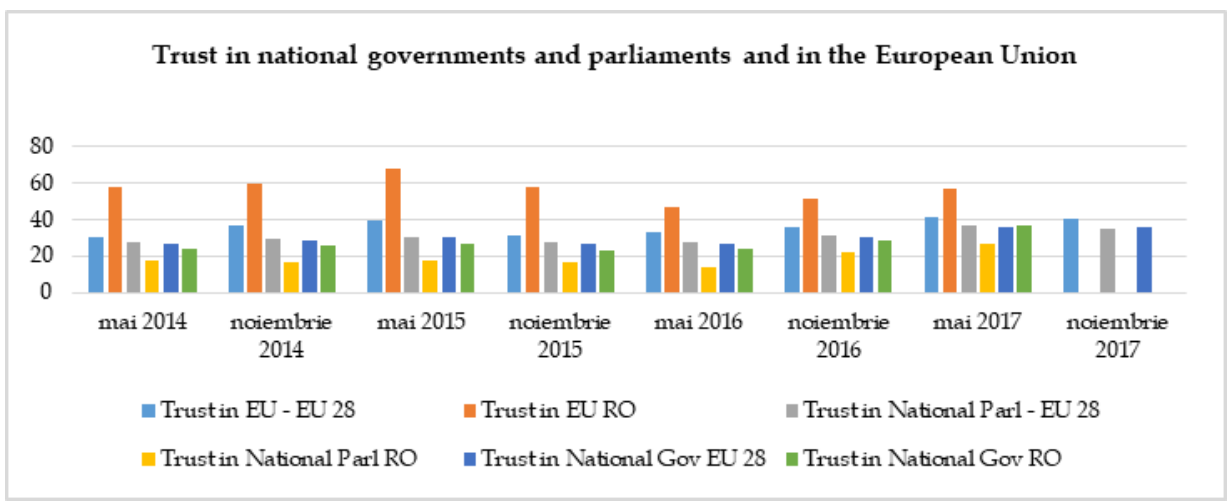

Table 6. Comparative trends in EU 28 and Romania - Lack of trust in national governments, parliaments and the EU, edited by the author with data from Standard Eurobarometer 81-88

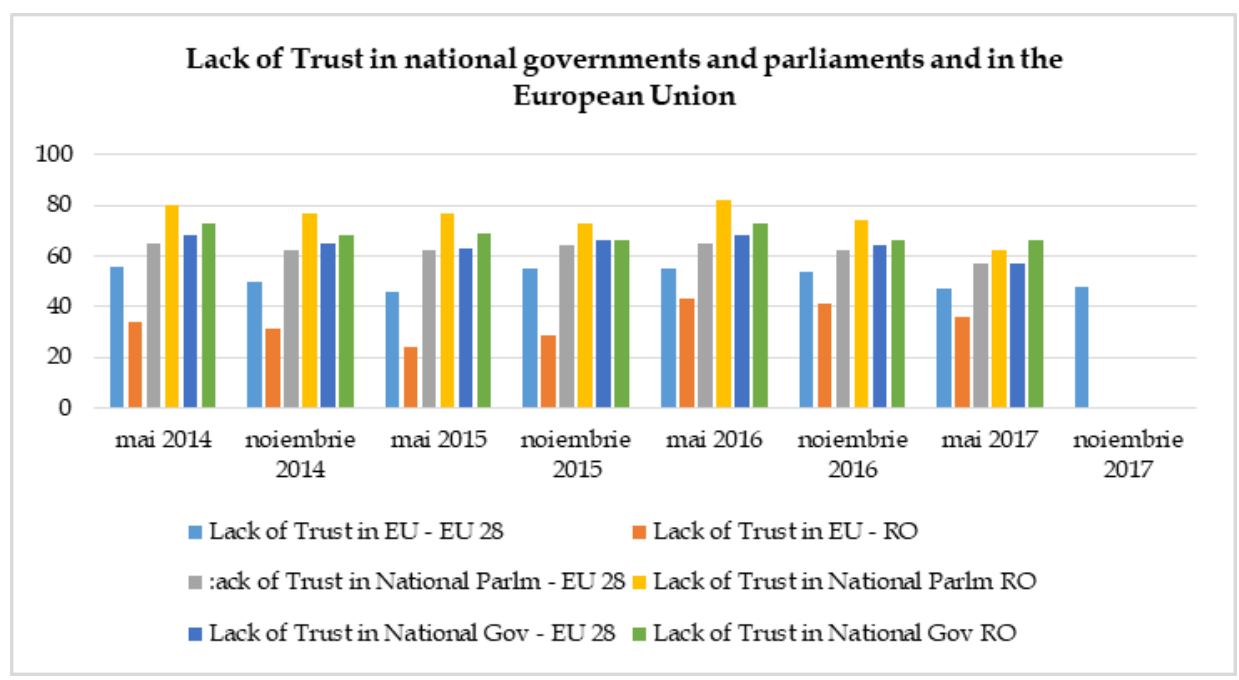


Table 7. Trust in the European Union: national results and EU 28 evolutions edited by the author with data from Standard Eurobarometer 81-88
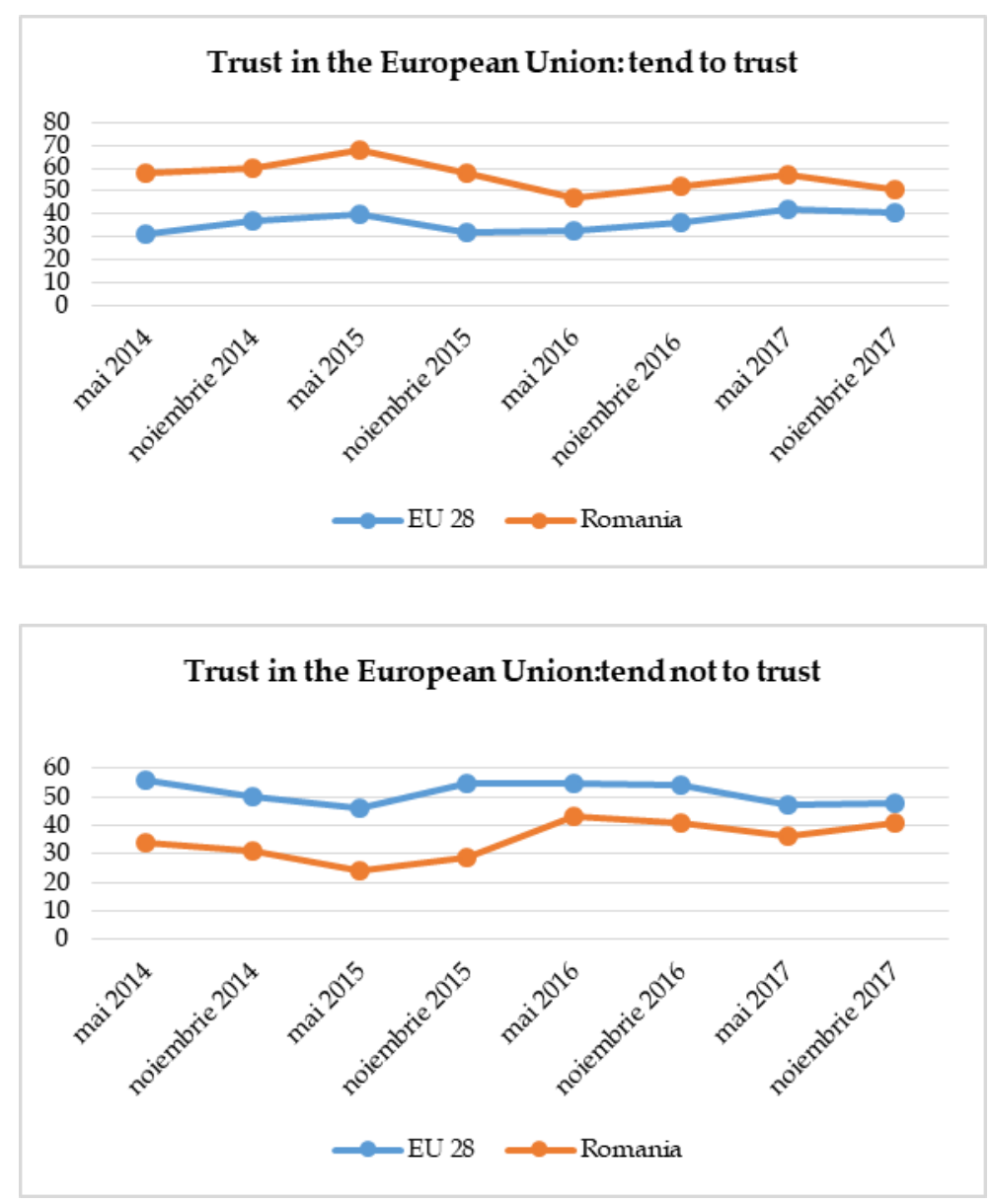
Table 8. The image of the European Union (total positive and total negative): national results and evolutions in EU 28, edited by the author with data from Standard Eurobarometer 81-88
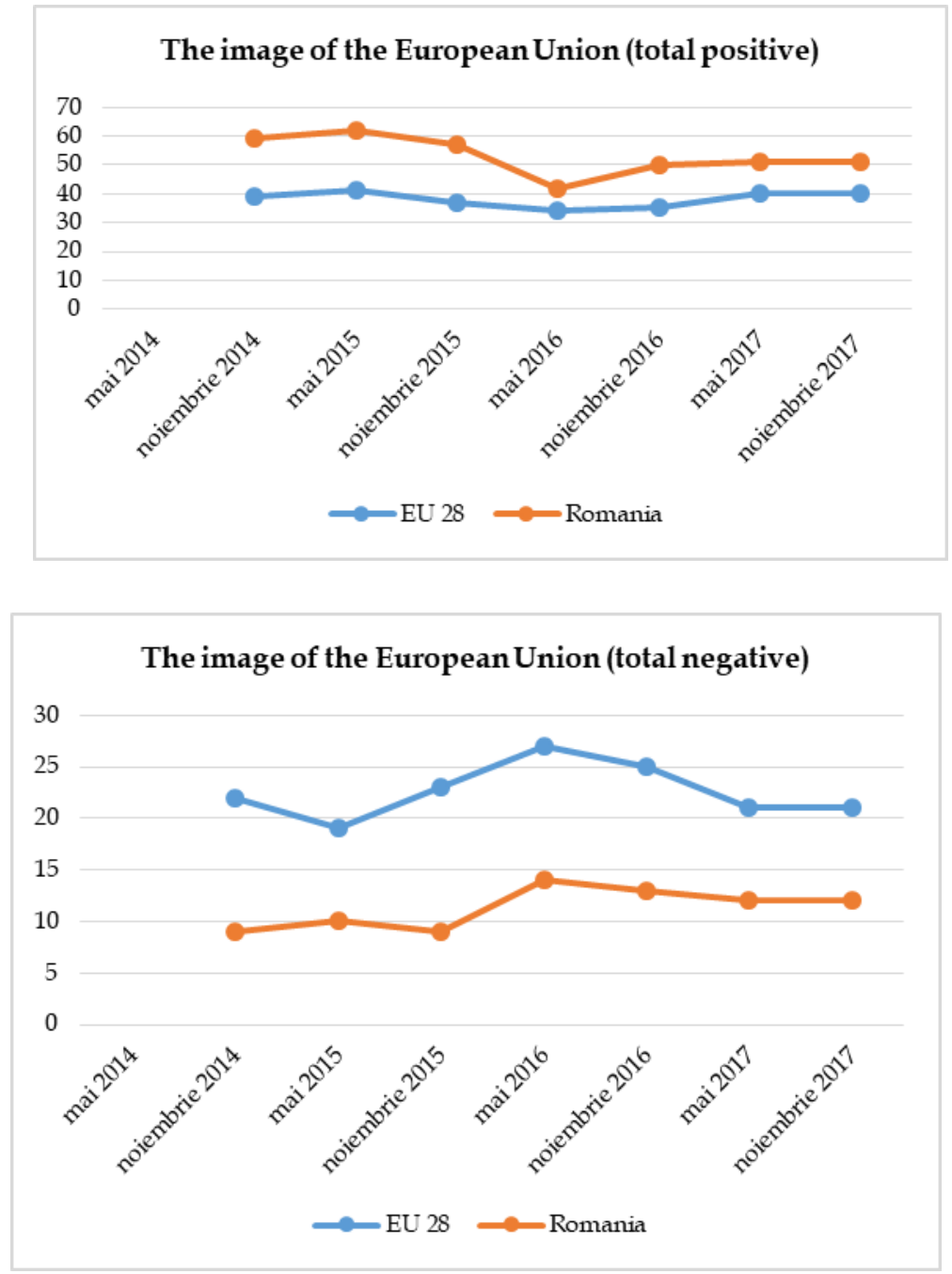


\section{AKNOWLEDGEMENTS}

"The study is an indicator in the project JEAN MONNET nr. 565269-EPP-1-ROEPPJMO-MODULE (2015-2018) coordinated by Miruna Troncotă at the National University for Political Science and Public Administration (SNSPA) which was co-funded by the Erasmus + programme of the European Commission".

\section{REFERENCES}

- $\quad$ APD (Asociația Pro Democratia). 2016. “Raport atitudinea romanilor fata de criza refugiatilor" [The attitude of the Romanians towards the refugee crisis] (pp. 21-64) http://www.apd.ro/wp-content/uploads/2016/04/Raport-decercetare-privind-criza-refugiatilor.pdf

- $\quad$ Baerthlein, Thomas. 2016. "Brexit lessons: we need European media for a European public sphere", Open Democracy 4 July 2016 https:/ / www.opendemocracy.net/can-europe-make-it/thomasbaerthlein/brexit-lessons-we-need-european-media-for-european-public-sphere - $\quad$ Bărbulescu, Iordan. 2015. Noua Europă. Identitate și model european. Iași: Polirom.

- Bârgăoanu, Alina, Durach, Flavia. 2013. “The Crisis of the European Union and its Reflection in the Romanian Public Sphere. Recent Findings", Romanian Journal of European Affairs, Vol. 13: 1.

- Bârgãoanu, Alina. 2011. Examenul Schengen. In cãutarea sferei publice europene. [The Schengen Test: In Search of the European Public Sphere] Bucharest: comunicare.ro.

- BBC. 2014. Eurosceptic 'earthquake' rocks EU, May 26, https://www.bbc.com/news/world-europe-27559714

- $\quad$ Boomgaarden, Hajo G., Rens Vliegenthart, Claes H. de Vreese and Andreas R.T. Schuck. 2010. News on the move: exogenous events and news coverage of the European Union. In Journal of European Public Policy, Vol. 17(4), pp. 506-526. 
- Börzel, Tanja. and Risse, Thomas. 2000. 'When Europe Hits Home: Europeanization and Domestic Change, European Integration online Papers (EIoP) Vol. 4 (2000) N 15; http:/ / eiop.or.at/eiop/texte/2000-015a.htm

- $\quad$ Brett, Daniel and Knott, Eleanor. 2014. "Presidential Romanian elections: Where do we go from here?", LSE Blogs Research on Southeast Europe, November 19, 2014. http://blogs.lse.ac.uk/lsee/2014/11/19/2014-presidentialromanian-elections-where-do-we-go-from-here/

- $\quad$ Brosius, Ana, de Vreese, van Elsas, Goldberg and Marquart, 2017. "Trust in the European Union. Effects of the Information Environment". Eventum Conference Barcelona https://eventum.upf.edu/_files/_event/_5261/_editorFiles/file/Ana\%20Brosiu s.pdf

- $\quad$ Brüggemann, M. and Katharina Kleinen-von Königslöw 2009 'Let's Talk about Europe': Why Europeanization Shows a Different Face in Different Newspapers, European Journal of Communication 2009; 24; 27

- $\quad$ Brüggemann, M., Sifft, S., Kleinen von Königslöw, K., Peters, B. and Wimmel, A. 2006. 'Segmented Europeanization: The Transnationalization of Public Spheres in Europe; Trends and Patt erns', TranState Working Papers , no. 37htt ps://www.econstor.eu/dspace/bitstream/10419/24950/1/514648759.PDF - Brüggemann, Michael and H. Schulz-Forberg. 2009. Becoming PanEuropean? Transnational Media and the European Public Sphere. The International Commnication Gazette 71(8): 693-712.

- $\quad$ Brüggemann, Michael, Königslöw, Kleinen von, Katarina. 2007. “Let's talk about Europe: Explaining Vertical and Horizontal Europeanization in the Quality Press". TranState Working Papers 60, University of Bremen, Collaborative Research Center 597: Transformations of the State.

- $\quad$ Carp, Radu. 2015. “The Well-Tempered Optimism of Romanians 8 Years After Joining The European Union", Konrad Adenauer Foundation, http://www.kas.de/wf/doc/kas_43986-1522-19-30.pdf?160125155431

- Corbu, N., Frunzaru, V., Boțan, M., \& Schifirnet,, C. 2011. Stabilirea agendei publice referitoare la Uniunea Europeană: Alegerile Europarlamentare din 2009, în România [Setting the Public Agenda for the European Union: The 2009 European Elections in Romania]. Romanian Journal of Sociology. 3-4 
- Dâncu, Vasile. 2015. “The Facebook Generation, Elections, and Political Tribes. The case of Romania" in Geoffrey Pleyers, Ionel N. Sava (eds.) Social Movements in Central and Eastern Europe. A renewal of protests and democracy, București: editura Universității din București, 139-150.

- De la Porte, Caroline; van Dalen, Arjen, 2016, Europeanization of National Public Spheres? : Cross-national Media Debates about the European Union's Socio-economic Strategy, European Politics and Society, Vol. 17, No. 3, p. 279-293.

- $\quad$ De Vreese, Claes H. 2007. "The EU as a public sphere”, Living Rev. Euro. Gov., Vol. $\quad 2, \quad 3$. http://edoc.vifapol.de/opus/volltexte/2011/2480/pdf/1reg_2007_3Color.pdf

- De Vreese, Claes H., 2004. "The effects of frames in political television news on audience perceptions of routine political news", Journalism \& Mass Communication Quarterly, 81(1): 36-52

- $\quad$ De Vreese, Claes, Banducci, Susan, Holli and Boomgaarden, Hajo. 2006. "The News Coverage of the 2004 European Parliamentary Election Campaign in 25 Countries", European Union Politics, Vol 7, 4: p.477-504.

- Dobrescu, Paul and Bârgãoanu, Alina. 2012, “The Discourse of Romanian Elites on an EU Topic: Islands of Europeanization in the Romanian Public Sphere", Revista Română de Comunicare, http://journalofcommunication.ro/oldsite/archive2/024/24/dobrescu_bargaoa nu_24.pdf

- Durach, Flavia and Bârgãoanu, Alina. 2013. "Euro-enthusiasm in Romania: Is the Romanian Youth in Favor of the European Union or too Apathetic to Object?, Romanian Journal of Communication and Public Relations, vol 15, no. 1, April 2013, pp 57-73.

- Durach, Flavia. 2016. Public Opinion towards the EU Triumphalism, Euroscepticism or Banal Representations? Cambridge Scholars Publishing.

- $\quad$ Eder, Klaus and Trenz, Hans-Jorg. 2007. "Prequisities of Transnational Democracy and Mechanisms for Sustaining It: The Case of European Union". In: Kohler-Koch, Beate and Rittberger, Berthold (Eds.) Debating the Democratic Legitimacy of European Union. Lanham, Boulder, New York, Toronto, Plymouth, UK: Rowman \& Littlefield Publishers. 
- $\quad$ EEAS. 2016. https://eeas.europa.eu/delegations/egypt/2559/refugeecrisis-puts-our-identity-test-federica-mogherini-ep_en

- $\quad$ Eriksen, Erik. 2005. "An Emerging European Public Sphere", European Journal of Social Theory, Vol 8, 3: 341 - 363.

- $\quad$ EU Observer. 2014. "Slovakia's EP election turnout set for all-time low of 13\%", May 25, https://euobserver.com/eu-elections/124278

- European Commission, "Standard Eurobarometers", http://ec.europa.eu/commfrontoffice/publicopinion/index.cfm/Survey/index $\# \mathrm{p}=1$ \&instruments $=$ STANDARD

- $\quad$ Flockhart, Trine. 2010. "Europeanization or EU-ization? The Transfer of European Norms across Time and Space". JCMS: Journal of Common Market Studies Vol. 48, 4: 787-810.

- $\quad$ Fossum, Johm Erik and Schlesinger, Philip (eds.) .2007. The European Union and the Public Sphere: A Communicative Space in the Making?. London and New York: Routledge.

- Garavoglia, Matteo. 2011. „Democracy in Europe: Politicizing Champions for the European Public Sphere, IAI WORKING PAPERS 11 | 14 June 2011, http://www.iai.it/sites/default/files/iaiwp1114.pdf

- Goudenhooft, Gabriela. 2015. "In the search of identity: the Romanian journalistic discourse and the function of Europeanization of the public sphere", Journal of Identity and Migration Studies, Vol. 9, 2:53-66.

- Gov.uk. 2013. EU Speech of David Cameron, https://www.gov.uk/government/speeches/eu-speech-at-bloomberg

- Guardian. 2014. "UKIP rthe European elections political earthquake", May 26, https://www.theguardian.com/politics/2014/may/26/ukip-europeanelections-political-earthquake

- Habermas, Jurgen. (1962/1989) The Structural Transformation of the Public Sphere: An Inquiry into a Category of a Bourgeois Society, trans. T. Burger and F. Lawrence. Cambridge, MA:MIT Press

- Harteveld, Eelco, Schaper, Joep, De Lange, Sarah L. and Van Der Brug, Wouter. 2018. "Blaming Brussels? The Impact of (News about) the Refugee Crisis on Attitudes towards the EU and National Politics", JCMS Vol.56, 1:157-177. 
- $\quad$ Harteveld, Meer, \& Vries, 2013. “In Europe we trust? Exploring three logics of trust in the European Union", European Union Politics, Vol 14, 4: 542565

- Heikkila, Heiki and Kunelius, Risto. 2014." Journalists imagining the European public sphere", Javnost -The Public, 13(4), pp. 63-79.

- Innerarity, Daniel. 2006. El nuevo espacio público, Madrid: Espasa,

- INSCOP. December $2015 . \quad$ "Problema migrației". http://www.inscop.ro/wp-content/uploads/2015/09/INSCOP-09.2015crizaimigrantilor1.Pdf

- INSCOP. $\quad 2015 . \quad$ "Criza imigrantilor". http://www.inscop.ro/wp-content/uploads/2015/12/Problema-migratiei1.pdf - Ion, Oana-Andreea (coord.). 2016. Studying Europeanization. Different Theoretical Lenses and New Methodological Approaches. Bucharest: Tritonic.

- $\quad$ IRES. 2014. "Generația Facebook și convergența media au dus la Victoria lui Klaus Iohannis". http://www.ires.com.ro/articol/282/genera-ia-facebookși-convergența-media-au-dus-la-victoria-lui-klaus-iohannis

- IRES. 2015. "Percepții publice privind criza imigranților" http://www.ires.com.ro/uploads/articole/ires_perceptii-publice-privind-crizaimigrantilor.pdf

- IRES. 2016. "Percepții și reprezentări Brexit" http://www.ires.com.ro/uploads/articole/ires_perceptii_si_reprezentari_brexit _raport-narativ.pdf

- J Janning, Josef. 2018." EU Cohesion Monitor 2018”, European Council for Foreign Relations, http://www.ecfr.eu/page//ECFR238_EU_COHESION_MONITOR_2018.pdf

- $\quad$ Kandyla, A., \& de Vreese, C. H. (2011). News media representations of a common EU foreign and security policy. A cross-national content analysis of CFSP coverage in national quality newspapers. Comparative European Politics, 9(1), 52-75.

- $\quad$ Kokhanova, Olga. 2012. “Europeanization of National Public Spheres: Comparative analysis of the readers' online debate on European issues in German and Spanish newspapers", Working Papers WP 2012-02, Centre for 
German and European Studies http://www.zdes.spbu.ru/assets/files/wp/2012/WP_2012_2_Kokhanova.pdf - Koopmans, Ruud and Statham, Paul. 2010. The Making of a European Public Sphere: Media Discourse and Political Contention, New York: Cambridge University Press, pp. 1-12.

- Koopmans, Ruud, Erbe, Jessica. 2004. “Towards a European public sphere? Vertical and horizontal dimensions of Europeanised political communication". Innovation. The European Journal of Social Science Research 17(2):97-118.

- Koopmans, Ruud. 2007. "Who inhabits the European public sphere? Winners and losers, supporters and opponents in Europeanised political debates", European Journal of Political Research 46: 183-210.

- Lauristin, Marju, 2007. "The European Public Sphere and the Social Imaginary of the 'New Europe', European Journal of Communication, Vol 22, issue 4. - Machill, Marcel, Beiler, Markus and Fischer, Corinna. 2006. 'Europetopics in Europe's media. The debate about the European public sphere: a metaanalysis of media content analyses'. European Journal of Communication 21: 57- 88.

- Mediafax, 2016 http://www.mediafax.ro/social/criza-imigrantilorromania-va-primi-2-475-de-refugiati-potrivit-deciziei-jai-totalul-pana-acumfiind-4-837-14738511

- Merijes, Markus. 2013. „Euro-crisis as a catalyst of the Europeanization of public spheres. A cross-temporal study of the Netherlands and Germany”, LEQS Paper No. 62/2013. http://www.lse.ac.uk/europeaninstitute/Assets/Documents/LEQS-Discussion-Papers/LEQSPaper62.pdf

- $\quad$ Milewski, Natalia and Gusek, Damian. 2013. "Representations about the European Union in Spanish, Polish and Romanian TV", Revista Română de Jurnalism și Comunicare, Anul VIII (XII), nr. 4 (43).

- Mocanu Oana, Bogdan Mureșan, Eliza Vaș and Mihai Sebe, “Romania 10 years in the European Union". 2017. http://ier.ro/stiri/raport-ierrom $\%$ C3\% A2nia-\%E2\%80\%93-10-ani-\%C3\%AEn-uniuneaeuropean $\%$ C4\% 83. html 
- $\quad$ Momoc, Antonio. 2016, „Political Angles in the Romanian Online Media about the Refugees' Crisis and Islam. Traian Băsescu Case", Europolity, Vol. 10, No. 1/2016: 71-86.

- $\quad$ Nizinik, Józef. 2017. "The awaking of the European public sphere amid the crisis", http://www.ifispan.pl/wp-content/uploads/2017/11/The-awakingof-the-European-public-sphere-amid-the-crisis-1_2017.pdf

- Offerhaus, Anke; Mollen, Anne; Hepp, Andreas. 2014. "Europe is already all around, but no one notices": The Europeanization of public spheres in regional newspaper reporting, TranState Working Papers, No. 183.

- $\quad$ Pfetsch, Barbara (unter Mitarbeit von Silke Adam, Barbara Berkel und Juan Diez Medrano). 2004. Europub.com: Integrated Report: The Voice of the Media in European Public Spheres: Comparative Analysis of Newspaper Editorials. http: \\europub.wz-berlin.de

- Pricopie, Valentina, 2014. "Debating Europe in Romanian Parliament", Procedia - Social and Behavioral Sciences 149: 772 - 777.

- $\quad$ Radaelli, Claudio.M. 2004. 'Europeanisation: Solution or Problem?', 2004, European Integration online Papers , vol. 8, no. 16, ://eiop.or.at/eiop/texte/2004-016a

- $\quad$ Radu, Loredana and Bârgăoanu, Alina. 2015." Advocates or Challengers of Europeanization? An Inquiry into The Discourse Of The Romanian Elites on the European Union in the Context of EU Elections 2014, Transylvanian Review of Administrative Sciences, No. 46 E:162-177.

- Radu, Loredana, 2016. "Unconditional Trust? Public Opinion Towards the EU in Romania", Journal of Media Research, Vol. 9, 1:60-79.

- Reuters. 2015. "U.N. expects Europe's refugee flow to top 1 million" September 29, https://www.reuters.com/article/us-europe-migrants-unidUSKCN0SU1F320151105.

- $\quad$ Risse, Thomas and Van de Steeg, Marianne. 2003. "An Emerging European Public Sphere? Empirical Evidence and Theoretical Clarifications Paper presented to the conference on the "Europeanisation of Public Spheres, Political Mobilisation, Public Communication and the European Union", 
"Science Center Berlin, June $20 \quad-\quad 22$, 2003. www.userpage.fuberlin.de/ atasp/texte/030624_europeanpublicsphere.pdf.

- $\quad$ Risse, Thomas, Maria Green Cowles and James Caporaso. 2001. "Europeanization and Domestic Change: Introduction", in Maria Green Cowles, James A. Caporaso and Thomas Risse (eds), Transforming Europe. Europeanization and Domestic Change, Ithaca, Cornell University Press, 2001, p. 1-20.

- $\quad$ Risse, Thomas. 2010. A Community of Europeans? Transnational Identities and Public Spheres. Ithaca: Cornel University Press.

- $\quad$ Saurugger, Sabine. 2014. "Europeanisation in times of crisis". In Political Studies Review. Vol 12, pp. 181-192.

- $\quad$ Sebe, Mihai, 2015. "Romania's stance in the issue of the Refugees crisis: Preliminary Observations", IED Working Paper, December 2015, http://www.iedonline.eu/.

- Sebe, Mihai, 2016," Romania. Soul search, national and European identity and politics in a time of trouble", Building Bridges paper series March 2016

https://www.ifri.org/sites/default/files/atoms/files/sebe_soul_search_nation al_and_european_politics.pdf.

- $\quad$ Sifft, Stefanie, Michael Brüggemann, Katharina Kleinen-V. Königslöw, Bernhard Peters, Andreas Wimmel, 2007. "Segmented Europeanization: Exploring the Legitimacy of the European Union from a Public Discourse Perspective", JCMS, Vol 45. 1:127-55.

- $\quad$ Slaatta, Tore. 2006. "Europeanisation and the news media: issues and research imperatives". Javnost - The Public, Vol. 13. 1:5-24.

- State of the Union. 2016. https://ec.europa.eu/commission/state-union2016_ro.

- Trenz, Hans Jeorg. 2005. “The European Public Sphere: Contradictory Findings in a Diverse Research Field". European Political Science, 4:407-420.

- Trenz, Hans-Jörg. 2004. "Media Coverage on European Governance. Exploring the European Public Sphere in National Quality Newspaper"s, in: European Journal of Communication, 19 (3): 291 - 319. 
- Trenz, Hans-Jörg. 2014. New Media Dynamics and European Integration. In Revista Científica de Información y Comunicación, 10, pp. 35-51.

- Troncotă, Miruna. 2015. "The Formation of The Juncker Commission And Its Impact On The Western Balkans", Europolity - Continuity and Change in European Governance (Europolity - Continuity and Change inEuropean Governance), issue: 2 / 2014, pages: 153-17.

- $\quad$ Van de Steeg, Marianne. 2002. "Rethinking the Conditions for a Public Sphere in the European Union". European Journal of Social Theory 5(4): 499-519. - Wesselink, Bram. 2017. "Brexit and the European Public Sphere (Europeanization in British public debates)", Master thesis.

- Wiener, Antje and Diez, Thomas. 2009. European Integration Theory (second edition), Oxford, Oxford University Press.

- Wolf, Marie and Ossewaarde, Marinus. 2017. "The political vision of Europe during the 'refugee crisis': missing common ground for integration, Journal of European Integration, Vol. 40, 1:33-50. 
EUROPOLITY, vol. 12, no. 1, 2018 